\title{
Global Sourcing Decisions and Firm Productivity: Evidence from Spain
}

\author{
Wilhelm K. Kohler \\ Marcel Smolka
}

CESIFO WORKING PAPER NO. 2903

CATEGORY 8: TRADE POLICY

DECEMBER 2009

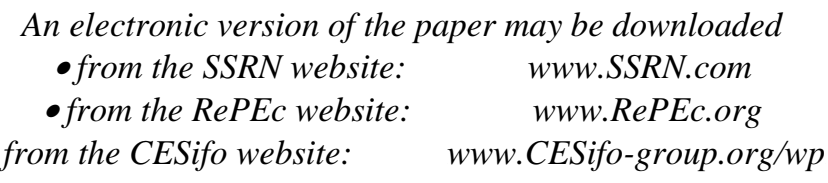




\title{
Global Sourcing Decisions and Firm Productivity: Evidence from Spain
}

\begin{abstract}
We investigate the link between productivity of firms and their sourcing behavior. Following Antràs \& Helpman (2004) we distinguish between domestic and foreign sourcing, as well as between outsourcing and vertical integration. A firm's choice is driven by a hold-up problem caused by lack of enforceable contracts. We use Spanish firm-level data to examine the productivity premia associated with the different sourcing strategies. We find strong empirical support for the predictions of the model.
\end{abstract}

JEL-Code: F14, F23, L22, L23.

Keywords: productivity, outsourcing, intra-firm trade, foreign direct investment, incomplete contracts, firm-level data.

\author{
Wilhelm K. Kohler \\ University of Tübingen \\ Nauklerstrasse 47 \\ 72074 Tübingen \\ Germany \\ wilhelm.kohler@uni-tuebingen.de
}

\author{
Marcel Smolka \\ University of Tübingen \\ Nauklerstrasse 47 \\ 72074 Tübingen \\ Germany \\ marcel.smolka@uni-tuebingen.de
}

An earlier version of this paper was presented at the conference "Fragmentation, Offshoring of Activities, and Vertical Intra-Industry Trade", held at The University of Michigan, Gerald R. Ford School of Public Policy, October 16-17, 2009. We thank seminar participants at the University of Tübingen, the 5th Danish International Economics Workshop, Aarhus School of Business, the International Workshop on Firm and Product Heterogeneity, H.U. Brussels, the ETSG 2009, University of Rome, the Japanese and U.S. International Trade Conference, University of Michigan, the 9th FIW Workshop, Vienna, and the THE Christmas Workshop 2009, University of Hohenheim, for useful comments. We are especially grateful to Jörn Kleinert, Jagadeesh Sivadasan, and Dieter Urban for very helpful suggestions. Thanks are also due to Inga Heiland and Ina Charlotte Jäkel for editorial assistance. 


\section{Introduction}

During the past decade, trade theory has turned micro: The individual firm has entered the stage of analysis. Of course, this is of interest only to the extent that firms are not entirely symmetric. We have ample evidence indicating that firms exhibit substantial heterogeneity in the degree, as well as the organizational form of internationalization. Importantly, this heterogeneity is not random, but features a characteristic pattern. The general picture is one of so-called "exporter-premia", whereby exporting firms show higher performance in several dimensions than non-exporting firms, most notably in the level of productivity; see Bernard et al. (2007) for a convenient survey. A similar pattern is also observed for horizontal FDI; see Helpman et al. (2004) and Helpman (2006). The dominant theoretical explanation of such heterogeneity in exports and FDI invokes the celebrated model of firm heterogeneity in a monopolistic competition framework developed in Melitz (2003). This explanation features self-selection of firms based on productivity. In other words, the causation runs from productivity to exports or FDI. However, such causality is more difficult to establish empirically than the pattern of heterogeneity as such; see Bernard et al. (1999). Although the bulk of the literature focuses on exports and horizontal FDI, Bernard et al. (2007) find a picture of premia also on the import side. In other words, more productive firms tend to do both, more exporting and more importing than less productive firms. Any theoretical explanation for an "importer premium" must address firms' sourcing behavior. Production requires intermediate inputs, and in many cases these inputs may be obtained either domestically or through imports. Moreover, provision of intermediates may take different organizational forms, such as arms-length market transactions or vertical integration within a firm's own boundary. In other words, a firm's sourcing decision for intermediates involves a location dimension (domestic or offshore) and an organizational dimension (markets or in-house). Do we find a characteristic pattern performance premia across these sourcing modes? What does this pattern look like? How can it be explained?

Drawing on Antràs (2003) as well as Melitz (2003), Antràs \& Helpman (2004) develop a model of global sourcing that addresses both, the location of sourcing and its organizational mode. The model emphasizes a hold-up problem that arises if the inputs in question are relationship-specific and cannot be contracted. As a result, the firm and the input supplier face the need to negotiate on dividing the surplus from the relationship. Institutional environments in developed economies typically offer several organizational forms that firms may rely on for their sourcing strategies. 
Drawing on Grossman \& Hart (1986), Antràs \& Helpman (2004) assume that firms may choose between two forms, one relying on arms-length transactions, the other relying on so-called vertical integration. The two forms differ in the outside options of the two negotiating parties, whereby vertical integration gives the firm a property right in the input. This enhances the firm's outside option when negotiating with the supplier about sharing the fruits of the relationship, but it also reduces the incentive for the input supplier to invest in that relationship. This is the key trade-off modeled in Antràs \& Helpman (2004). The model generates relatively sharp predictions where a firm's sourcing strategy is determined by its productivity as well as certain structural characteristics of the underlying production relationship. Antràs \& Helpman (2004) assume complete lack of contractibility, which may risk overdoing the point. In Antràs \& Helpman (2008), the model is extended to allow for a varying degree of contractibility over a continuum of tasks required for each of the two inputs in question. The extended model generates additional predictions, but the spirit of the original model survives without a stain.

Empirical evidence on firm heterogeneity in importing and sourcing is less abundant than evidence on exports and horizontal FDI. The reason has to do with data limitations. Offshoring is notoriously difficult to measure. This is aggravated by the need to observe the prevalence of organizational forms, if we aim at a comprehensive empirical investigation that covers both dimensions of sourcing. As a result, empirical analysis seems inherently more challenging in this line of research than for the export side, as suggested by Greenaway and Kneller (2007, p.F156). No wonder, then, that the literature on firm heterogeneity in trade has mainly focused on exports and FDI, and less on imports and sourcing. Existing empirical work has mostly focused on the organizational form of offshoring, thus ignoring domestic sourcing strategies; see Defever \& Toubal (2007) and Nunn \& Trefler (2008). However, a consistent investigation of "importer-premia", or a full test of the Antràs-Helpman model, requires a comprehensive approach that includes observing both, domestic sourcing as well as import sourcing.

In this paper, we present evidence on the pattern of sourcing strategies of manufacturing firms drawing on Spanish firm-level data. A crucial feature of our data is that they allow us to consistently investigate both sourcing dimensions (location and organizational form) in a unified setting. Tomiura (2007) provides mainly evidence on both dimensions from a Japanese data set, without investigating performance premia associated with different sourcing modes, and without observing the organizational dimension for domestic sourcing. A recent study by Federico (2009), relying on 
Italian firm-level data, does observe all possible dimensions, and it looks at the relationship between firm productivity and sourcing behavior. However, this relationship is inherently more complex in this setup than in the standard case because of the hold-up problem mentioned above. For this reason, we first present a theoretical model of the hold-up problem that highlights how firm productivity interacts with structural characteristics of the underlying production relationship in determining a firm's sourcing strategy.

Given this interaction, can we expect a clear pattern looking at "productivity-premia" alone? Our theoretical section tells us we can do so only up to a point. In other words, we need to bring in certain controls. It also tells us that we need to be very cautious about whether the units of observation are indeed firms as defined in the model. Theory defines the firm as a true headquarter that decides about the organizational form of sourcing. We must therefore avoid our data to be "contaminated" by firms who are in fact positioned at the opposite side of the hold-up problem, i.e., purchasing an input from a foreign or domestic headquarter. Our data set is unique in that it allows us to clearly separate firms that correspond to the theoretical notion of a headquarter from those who are themselves subsidiaries of foreign or domestic parental companies.

Our paper is structured as follows. Section two presents the essentials of the hold-up model of global sourcing, aiming at a rigorous derivation of the "sourcing-premia" implied by this model. In section three, we then describe our data set and present a few descriptive statistics. Section four comes in two parts. First, we compare the true productivity distributions of subsets of firms that differ in their sourcing strategies. More specifically, we compare firms engaged in domestic outsourcing versus domestic vertical integration, as well as firms engaged in foreign outsourcing versus foreign vertical integration. A final comparison is between firms with offshore sourcing (whether at arms-length or with vertical integration) versus domestic sourcing. Secondly, we estimate "sourcing-premia" by regressing firm productivity on dominant sourcing strategies, as well as a host of controls. Section five concludes with a brief summary and outlook on open questions and further research.

\section{A theory of sourcing without contractibility}

Stripped down to its bare bones, what are the essentials of the "hold-up model" of global sourcing? A key tenet of all models in the spirit of Antràs (2003) is that production requires essential inputs that the firm cannot generate within its firm (or command) hierarchy, but must be obtained from a 
supplier. Importantly, the line separating "firm-inputs" and "supplier-inputs" is exogenous to the model. What is endogenous is the organizational mode and location of the "supplier-input". Alternative modes of organization differ in their implications for the incentive structure for the firm and the input supplier. Thus, by choosing a specific organizational mode the firm may alleviate the problem of distorted input levels. More specifically, vertical integration lowers the incentive for the input supplier which may, therefore, not be an optimal strategy if the input looms large in the production relationship. In Antràs \& Helpman (2004,2008), this mechanism is extended to include firm heterogeneity. It turns out that firms select into different sourcing strategies, based on their productivity in interaction with importance of "firm inputs" relative to "supplier inputs" in the production relationship.

\subsection{The framework}

There are two types of agents, firms and input suppliers. Firms have access to some market where they raise revenue from selling final goods which are produced from two essential inputs that are provided, respectively, by the firms themselves (the so-called "headquarter service") and by the input suppliers. Input suppliers may either be located in the domestic economy or in the foreign economy, but all firms are assumed to be located in the domestic economy. Firms are unable to produce non-headquarter inputs which we shall henceforth call supplier-inputs. Therefore, they must always resort to input suppliers in order to generate revenue at all. In turn, production of both, the headquarter- and the supplier input, requires primary factors which must be purchased in the factor market of the country where the input provider is located.

Final goods feature product differentiation along the lines of Dixit \& Stiglitz (1977). Importantly, each firm produces its own distinct brand which affords market power. However, it also implies that inputs must be provided in a unique specification for each brand. We assume extreme specificity, so that any input, once provided, has economic value only from production and sale of the corresponding final good. This is called relationship-specificity. Moreover, we assume that the quality and/or quantity of input provision cannot be verified by a third party, so that firms and input suppliers cannot write enforceable contracts for input provision. Therefore, firms and input suppliers must ensure corresponding specifications, and when deciding about the amounts of labor to invest into generating their respective inputs, they expect to be pitted against each other in a negotiation about how to share the revenue from selling the output generated by their specific 
inputs. Negotiation is assumed to take the form of Nash-bargaining, with a bargaining power equal to $\beta$ for the firm, and $1-\beta$ for the input supplier. In addition to the variable cost of input provision, raising revenue from the production relationship requires an organizational effort which causes a fixed cost. As we shall detail below, the magnitude of this cost is assumed to differ across organizational forms as well as between locations of input provision.

For simplicity, we assume that in both countries input suppliers are in infinitely elastic supply, with zero outside options. Thus, any input-supplier is willing to engage in a production relationship with a firm, if and only if she may expect to obtain a share of the revenue that is at least equal to the cost of input provision. We assume perfect competition among input suppliers, so that in equilibrium the expected profit from participating in production as an input-supplier must be zero. A firm may thus attract a suitable input supplier by charging a participation fee which is equal to the surplus of the supplier's expected revenue-share over the cost for input provision. Note that this surplus need not be positive. If it is negative, then the firm must pay a participation price to the input-supplier.

The cost of input provision for the input supplier is determined by domestic factor prices or foreign factor prices, depending on whether a firm chooses a domestic or foreign supplier. This is the location dimension mentioned in the introduction. We assume a foreign location advantage for the supplier-input, which means that the foreign unit-cost of production is lower than the unit-cost under domestic factor prices. In the domestic economy, there is an infinitely elastic supply of potential firms that may enter the market, with an uncertain total productivity of the relationship between the two inputs. Firm entry evolves as in Melitz (2003), meaning that entry is governed by a sunk entry cost and zero expected profits from a potential relationship with an input supplier.

A fundamental premise of this type of models is that there is a key asymmetry between firms and input suppliers. In the very first stage of decision making, firms may "purchase" an outside option for the ex-post Nash-bargaining, which takes the form of property rights in the supplier-input. Following Antràs \& Helpman (2004), we call this vertical integration, but it is important to bear in mind that it does not mean the firm has command over the entire input provision. The meaning is as follows: If bargaining breaks down, the firm may invoke a property right on the supplier-input and still sell the output. However, securing this outside option involves two types of cost. First, there is an iceberg-type cost of invoking property rights in that the revenue 
accruing to the firm is only a fraction $\delta$ of market revenue. ${ }^{1}$ And secondly, the organizational fixed cost to the firm is higher with vertical integration than without. We call an organizational form of input provision that does not involve any acquisition of property rights outsourcing.

The organizational cost is likely to be larger if the firm relies on a foreign input supplier, whatever the organizational form of sourcing. Antràs \& Helpman (2004) make further assumptions that ultimately lead to following ranking of the fixed organizational cost: $F^{F I}>F^{F O}>F^{D I}>F^{D O}$, whereby a superscript $I$ and $O$ indicate vertical integration and outsourcing, respectively, while $F$ and $D$ indicate a foreign or domestic input supplier. All organizational costs are expressed in units of the (domestic) headquarter-input. One may also assume that $\delta$ is larger for an input provided domestically: $\delta^{D}>\delta^{F}$. Notice that this share is always zero if the firm chooses outsourcing.

With this legal environment of property rights, the firm may influence the expected pay-off from ex-post Nash-bargaining through an ex-ante choice of its organizational form of sourcing. More specifically, with vertical integration the share of revenue that accrues to the firm is equal to $\beta^{\ell I}:=\delta^{\ell}+\beta\left(1-\delta^{\ell}\right)$, and with outsourcing it is equal to $\beta^{F O}=\beta^{D O}=\beta<\beta^{\ell \kappa}$. Notice that $1-\delta^{\ell}$ times the revenue to be generated from the market represents the "gains from trade", trade meaning completion of the production relationship through successful Nash-bargaining.

\subsection{Decision making}

Decision making takes place in a multi-stage manner. In a first step, firms enter the market in order to find out about their productivity level $\theta$ (TFP). In stage 2, conditional upon $\theta$ being large enough to avoid losses from the subsequent stages, ${ }^{2}$ each firm decides about its optimal sourcing strategy, which means the simultaneous choice of a location $\ell=F$ or $\ell=D$ and an organizational form $\kappa=I$ or $\kappa=O$. In the third stage, the two input providers (i.e., the firm and the supplier) choose levels of their inputs that maximize the difference between their expected shares of revenue, to be generated from the relationship, and their respective cost of input provision. Expected shares depend on the anticipated Nash-bargaining power and the outside options of the two parties. Importantly, the revenue depends on the levels of each input chosen. Stage 4 then

\footnotetext{
${ }^{1}$ Antràs \& Helpman (2004) assume that the iceberg-cost parameter applies to the quantity of the final good produced. But this translates into an iceberg-cost parameter for revenue in a straightforward way, depending on the details of the revenue function that are not important for our purpose.

${ }^{2}$ Details of this first stage are as in Melitz (2003), and will not be looked at in detail here.
} 
involves production of the final good, with the revenue shared among the two input providers according to the Nash-bargaining solution. When contemplating entry, a potential firm anticipates its optimal choice of an organizational form in stage 2, which in turn will anticipate the optimal input levels emerging in stage 3. Thus, the sourcing strategy chosen is an integral part of a subgame-perfect equilibrium. In the following, we focus on stages 2 through 4 of decision making, employing the usual backward induction. ${ }^{3}$

Revenue (stage 4): Under the above assumptions, revenue $R$ is concave in $x$, the quantity of the final good produced:

$$
R(x)=A^{1-\alpha} x^{\alpha} \quad \text { with } \quad x=\theta y(h, m)
$$

The first expression follows from Dixit-Stiglitz-type product differentiation, with an elasticity of substitution equal to $1 /(1-\alpha)$, whereby $0<\alpha<1$. In the second expression, $y(h, m)$ is a linearly homogeneous production function for the final good, with input levels $h$ and $m$ for the headquarter service and the supplier-input, respectively, and $\theta$ as the firm-specific TFP-level. In the sequel, we denote the elasticity of $x$ with respect to $h$ by $\eta$. Given linear homogeneity, the elasticity with respect to $m$ is equal to $1-\eta$.

Input levels (stage 3): Input-providers simultaneously, but independently, choose input levels $h$ and $m$ that maximize $\gamma R(x)-c^{h}\left(w^{D}\right) h$ and $(1-\gamma) R(x)-c^{m}\left(w^{\ell}\right) m$, respectively, where $\ell$ denotes the location of the input supplier, and the terms $c^{h}(\cdot)$ and $c^{m}(\cdot)$ denote minimum unit-cost for the headquarter- and supplier-input, respectively, as functions of factor prices $w^{\ell}$. The parameter $\gamma$ denotes the revenue share accruing to the firm in ex-post Nash-bargaining. This depends on organizational choice $\kappa \in\{I, O\}$. However, for the time being we ignore this dependency, in order to better grasp the strategic role of this share. It can be shown that the optimal input levels (indicated by an asterisk) satisfy

$$
h^{*}=\gamma \alpha R^{*} \eta c^{h}\left(w^{D}\right) \quad \text { and } \quad m^{*}=(1-\gamma) \alpha R^{*}(1-\eta) c^{m}\left(w^{\ell}\right)
$$

In this equation, $R^{*}$ denotes the relationship-specific total revenue deriving from input levels $h^{*}$ and $\mathrm{m}^{*}$, determined simultaneously in this stage of decision making. The lack of contractibility introduces a distortion, relative to the environment with ex-ante enforceable contracts. Both inputs

\footnotetext{
${ }^{3}$ For the first stage of firm entry and a "general equilibrium" embedment of this sector, with a second numéraire sector, see Antràs \& Helpman (2004).
} 
are provided in less than optimal amounts, whereby the share parameter $\gamma$ determines the distortion (under-provision) of the headquarter input, relative to the supplier-input.

Organizational form (stage 2): In addition to the input levels $h^{*}$ and $m^{*}$, the firm's entire profit from the relationship depends on the participation fee that it may charge (or has to pay) the input supplier, as well as on the fixed organizational cost it has to bear. The participation fee is equal to $(1-\gamma) R^{*}-c^{m}\left(w^{\ell}\right) m^{*}$, which may be zero, positive, or negative. Equilibrium firm profits now emerge as

$$
\begin{aligned}
\Pi^{*} & =R^{*}-c^{h}\left(w^{D}\right) h^{*}-c^{m}\left(w^{\ell}\right) m^{*}-c^{h}\left(w^{D}\right) F^{\ell \kappa} \\
& =R^{*}[1-\gamma \alpha \eta-(1-\gamma) \alpha(1-\eta)]-c^{h}\left(w^{D}\right) F^{\ell \kappa}
\end{aligned}
$$

where $F^{\ell \kappa}$ denotes the corresponding organizational fixed cost in units of domestic labor. The second line uses the above first-order conditions on the two input levels. It is now crucial to recognize that $R^{*}$ depends on the organizational choice through the above mentioned property rights that may be acquired through vertical integration. Using $c_{y}$ to denote the unit-cost function dual to $y(h, m)$, we may write

$$
R^{*}=A\left[\frac{1}{\alpha \theta} c_{y}\left(\frac{c^{h}\left(w^{D}\right)}{\gamma}, \frac{c^{m}\left(w^{\ell}\right)}{1-\gamma}\right)\right]^{-\alpha /(1-\alpha)}
$$

Notice that the elasticity of $c_{y}$ with respect to $c^{h}\left(w^{D}\right)$ is equal to $\eta$, and analogously for the other input cost. Notice also that the lack of complete contracts affects maximum revenue that can be generated from the final goods market in a way which is equivalent to a tax on the two inputs. If $\gamma \neq 1 / 2$, then the "equivalent tax" also distorts the input mix. Equilibrium firm profits now emerge as

$$
\begin{aligned}
& \Pi^{*}=Z^{\ell \kappa} \theta^{\alpha(1-\alpha)}-c^{h}\left(w^{D}\right) F^{\ell \kappa} \\
& \text { where } \quad \mathrm{Z}^{\ell \kappa}:=\frac{\mathrm{A}[1-\alpha \gamma \eta-\alpha(1-\gamma)(1-\eta)]}{\left[\mathrm{c}_{\mathrm{y}}\left(\frac{\mathrm{c}^{\mathrm{h}}\left(\mathrm{w}^{\mathrm{D}}\right)}{\gamma}, \frac{\mathrm{c}^{\mathrm{m}}\left(\mathrm{w}^{\ell}\right)}{1-\gamma}\right) \alpha\right]^{\frac{\alpha}{1-\alpha}}}
\end{aligned}
$$

In stage 2 of the game, the firm chooses a sourcing strategy $\ell \in\{D, F\}$ and $\kappa \in\{I, O\}$ that maximizes profits $\Pi^{*}$. 


\subsection{Organizational modes of sourcing}

Equation (5) depicts a firm's profits from a production relationship as a linear function of $\Theta:=$ $\theta^{\alpha /(1-\alpha)}$. Remember that $0<\alpha<1$, hence $\Theta$ is unambiguously increasing in the productivity level $\theta$. The negative intercept in (5) represents the fixed organizational cost $F^{\ell \kappa}$ and the domestic unit-cost of the headquarter input. In turn, equation (6) reveals the slope of this line as a relatively complex function of the expected revenue share parameter $\gamma$ and the two countries' unit-cost for the inputs. Together, equations (5) and (6) reveal how firm productivity interacts with other characteristics of the production relationship in determining maximum firm profits. Setting demand characteristics $(A, \alpha)$ aside, these are the revenue share $\gamma$, reflecting the bargaining situation that stems from lack of enforceable contracts, the share of the firm's own input $(\eta)$, and the factor intensities of the two inputs, reflected in $c^{h}\left(w^{D}\right)$ and $c^{m}\left(w^{\ell}\right)$.

Up to this point we have not considered the choice of organizational form for the production relationship and the location of the input-supplier. How does firm productivity impact on these choices? We first discuss the organizational mode for a given location of supply. For any given sourcing market and for given characteristics of the production relationship $(\gamma, \eta)$, the slope term $Z^{\ell \kappa}$ tells us how differences in firm productivity $\Theta$ translate into differences in maximum operating profits. If there are fixed costs, these need to surpass a certain threshold for the firm to remain in the market. But this is not what we want to focus on now. We want to consider the role that $\gamma$ and $\eta$ play for the slope of the profit function. Antràs \& Helpman (2004) suggest that the organizational dimension of the sourcing strategy is best understood by first considering the effect of an unrestricted variation of the share parameter $\gamma$ on a firm's profit from the relationship with an input-supplier. Unrestricted simply means that the firm can pick $\gamma$ at will. It is obvious that a firm should not expect positive profits if its bargaining power approaches zero, $\gamma \rightarrow 0$. Remembering that the lack of enforceable contracts is equivalent to a tax on the two inputs, this case is recognized as an infinite "equivalent tax" on the headquarter-input, which wipes out all firm profits. Perhaps less obviously, a firm could not expect positive profits also if $\gamma \rightarrow 1$. Intuitively, in this case it would simply lack an essential input, since the input supplier lacks any incentive to invest in the relationship at all. Formally, in either of the two cases $\gamma \rightarrow 0$ and $\gamma \rightarrow 1$ we have $c_{y}(\cdot) \rightarrow \infty$, provided that $0<\eta<1$, and from (5) and (6) a firm's maximum profit function would be flat at $-c^{h}\left(w^{D}\right) F^{\ell \kappa}$. Independent of its productivity level, a firm would make negative 
maximum profits.

All of this suggests that there should be a level of $\gamma$ which maximizes the slope of our profit-line. We now call this the optimal value of $\gamma$, always bearing in mind that, ultimately, the choice of $\gamma$ will be subject to institutional restrictions. We shall turn to the equilibrium value of $\gamma$ below. Intuitively, the incentive problem of a high $\gamma$ is the more severe, the more important the supplier input for the relationship, as measured by the elasticity $1-\eta$. Put differently, for a given sourcing location, the optimal firm-share $\gamma$ should be increasing in $\eta$, the elasticity of the output $x$ with respect to the headquarter service. Antràs \& Helpman (2004) derive such a monotonic relationship for the optimal level of $\gamma$ as a function of $\eta$. Let us denote this relationship by $\gamma(\eta)$, with $\gamma>0$. It is interesting to note that the optimal value of $\gamma$ is independent of the unit-cost functions for the two inputs. Moreover, both $\gamma(\eta)$ and $Z^{\ell \kappa}$ are independent of the firm's productivity level $\theta$. Importantly, however, the level of the slope $Z^{\ell \kappa}$ that is reached at the optimal value of $\gamma$ does depend on the unit-cost $c_{y}(\cdot)$ and, thus, on the extent of the foreign cost advantage. For this reason, an increase in the firm's revenue share $\gamma$ also implies a variation in the slope $Z^{\ell \kappa}$ which comes about through the "equivalent tax" on the supplier-input in $\mathrm{c}^{\mathrm{m}}\left(\mathrm{w}^{\ell}\right) /(1-\gamma)$. It is also worth noting that, given a certain pattern of factor price differences between the two countries, the extent of the foreign cost advantage depends on the factor intensity of the supplier-input.

Next, we must recognize that the bargaining and institutional environment typically requires a discrete choice among limited set of options, rather than unconstrained optimization on $\gamma$. In our case, a firm has but two options. Vertical integration gives a revenue share equal to $\beta^{\ell I}:=\delta^{\ell}+$ $\beta\left(1-\delta^{\ell}\right)$, depending on the sourcing location. Outsourcing ties this share down to $\beta<\beta^{\ell I}$, independent of the sourcing location.

We proceed by first conditioning the firm's organizational choice on a given sourcing location $\ell \in\{D, F\}$. There is a critical value of $\tilde{\eta}$, implicitly defined through $\gamma(\tilde{\eta})=\beta<\beta^{\ell I}$, such that for any $\eta<\tilde{\eta}$ firms will never choose vertical integration, whatever their productivity, and independently of the fixed organizational cost. The supplier-input is simply too important in the production relationship. Ideally, the firm would even want to enhance the input-supplier's incentive through a revenue share larger than $1-\beta$, but by assumption $\beta$ is as low as the firm's share can 
get. $^{4}$

There is a further critical value $\bar{\eta}^{\ell}$ which is implicitly defined by $\gamma\left(\bar{\eta}^{\ell}\right)=\delta^{\ell}+\beta\left(1-\delta^{\ell}\right)$. It might be tempting to argue that for any elasticity value $\eta>\bar{\eta}^{\ell}$ the firm should choose vertical integration. However, this is not true. While it is true that in such industries the profit line has a larger slope for vertical integration than for outsourcing, i.e., $Z^{\ell I}>Z^{\ell O}$, this does not unambiguously dictate a vertical integration strategy, if integration involves a higher fixed cost of organization. Therefore, firm productivity must surpass some threshold level for this strategy to be worthwhile. Notice that $\Theta^{\ell O}$ depends on the level of $\eta$, conditional on $\eta>\bar{\eta}^{\ell}$.

For intermediate elasticity $\eta$-values that satisfy $\tilde{\eta}<\eta<\bar{\eta}^{\ell}$ the comparison of $Z^{\ell I}$ and $Z^{\ell O}$ is ambiguous. By monotonicity of $\gamma(\eta)$, for values in the upper range of this interval, we have $Z^{\ell I}>Z^{\ell O}$, so that the logic of the preceding paragraph applies, meaning that firms below some threshold productivity choose outsourcing instead of vertical integration, and vice versa. Thus, the true threshold level of $\eta$ that separates outsourcing firms from integrated ones is implicitly determined by $Z^{\ell I}=Z^{\ell O}$. We denote this level by $\eta^{\ell *}$, whereby $\tilde{\eta}<\eta^{\ell *}<\bar{\eta}^{\ell}$.

Summarizing what we have found so far, we may state that, whatever the input-supplier's location, we should expect to see more productive firms organizing their sourcing through vertical integration, and less productive firms to choose outsourcing. But there are two important caveats. First the threshold productivity levels $\Theta^{\ell O}$ separating the two types of firms generally depend on the headquarter-elasticity $\eta$. Secondly, if this elasticity falls below a threshold value, then firm productivity simply doesn't matter and all firms choose an outsourcing strategy. These caveats are important for estimation of "sourcing-premia" using the methodology of Bernard \& Jensen (1999), as we do in the empirical part of this paper. Suppose, for instance, that we compare productivity levels across sourcing strategies of firms in different industries with differing headquarter-elasticities. Suppose, moreover, that we have an industry with a headquarter-elasticity below $\eta^{\ell *}$ alongside others with elasticity values well above $\eta^{\ell *}$. If the former industry has a large mass of firms with a high productivity, then we should not expect to observe a clear productivity ranking across sourcing modes, unless we control for differences in the headquarter-elasticity. In the subsequent empirical section of this paper, we control for this "headquarter-elasticity effect"

\footnotetext{
${ }^{4}$ This may seem like a paradox. Why, after all, should a firm not be able to reduce its bargaining power? The underlying assumption here is that for some reason the firm cannot credibly commit to a lower bargaining power than $\beta$.
} 
through industry-fixed effects. ${ }^{5}$

\subsection{Adding the offshoring-dimension}

So far we have looked at organizational choice assuming that the input-supplier's location is given. We now look at the choice of location explicitly. Remember our assumption relating to the fixed organizational cost: $F^{F I}>F^{F O}>F^{D I}>F^{D O}$. With this ranking, it is obvious that foreign sourcing will never be attractive, unless the foreign economy has an absolute cost advantage in the supplier input. In terms of equation (6), this requires $c_{y}\left(\frac{w^{D}}{\gamma}, \frac{w^{F}}{1-\gamma}\right)<c_{y}\left(\frac{w^{D}}{\gamma}, \frac{w^{D}}{1-\gamma}\right)$. We therefore assume that this inequality holds, which implies that $Z^{F \kappa}>Z^{D \kappa}$. We may then say that a firm's productivity level $\Theta$ is a leverage for the cost-advantage of foreign sourcing. Moreover, we assume that the extent of the foreign cost advantage is specific to the industry, not the firm. With both dimensions explicitly in the picture, we have a more complex choice problem. Figure 1 depicts a case where all possible sourcing strategies will emerge in equilibrium, whereby the headquarter-elasticity is assumed to satisfy $\eta>\eta^{F *}>\eta^{D *}$. Hence, the profit-lines for vertical integration are steeper than those for outsourcing in either location. At the same time, by the assumption of a foreign cost advantage, they are steeper for offshoring than for domestic sourcing for either of the two organizational modes. However, these assumptions do not guarantee that all four sourcing strategies will appear in equilibrium. We must distinguish between two types of “degenerate" equilibria.

First, we may have a case where the fixed cost-disadvantage of the integration strategy over the outsourcing strategy is small enough and/or the variable cost advantage large enough for integration to be the dominant strategy for all firms, irrespective of their productivity. ${ }^{6}$ This may happen for the foreign or the domestic location, or indeed for both. However, even in this latter case, we would still observe foreign integration only for more productive firms.

\footnotetext{
5 There is a further caveat that we should like to add here. Suppose that we reverse the fixed cost assumption, such that $F^{\ell I}<F^{\ell O}$, which does not seem all that implausible. Then we would observe firms with a headquarter-elasticity below $\eta^{\ell *}$ potentially pursuing both strategies. If so, it would indeed be the less productive firms that do vertical integration. It becomes obvious that the predictions of the model heavily depend on the fixed cost ranking assumption. As we shall see in the empirical section, the case assumed in the text is supported by our data.

${ }^{6}$ All of this is, of course, conditional on positive expected profits, i.e., on remaining in the market in the first place.
} 
Second, the fixed cost of offshoring relative to domestic sourcing may be small enough, compared to the locational advantage in variable cost, so that the equilibrium features only offshoring firms. This may happen independently for either of the two organizational modes. But again, we would still expect to see the more productive firms pursuing an integration strategy.

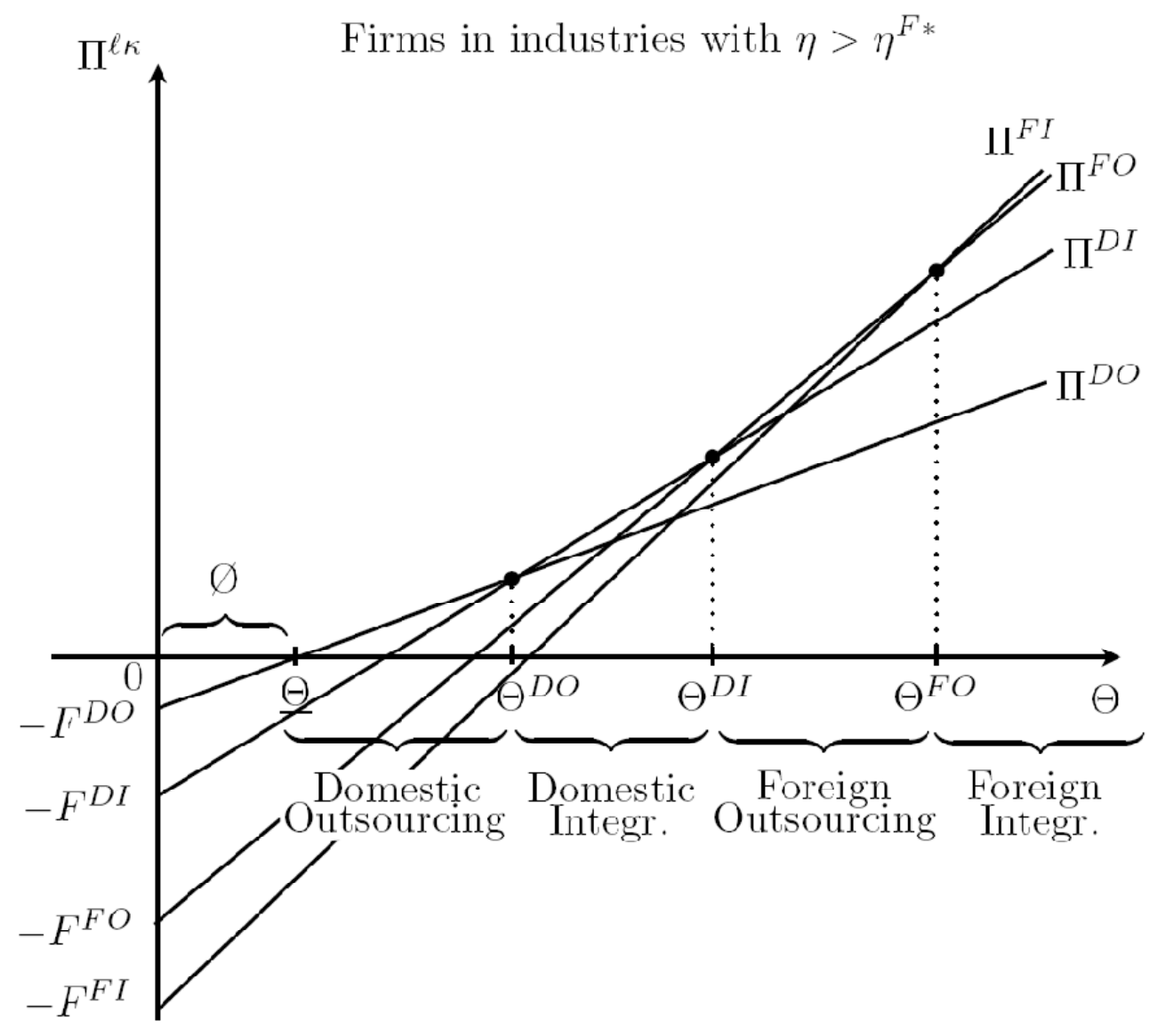

Figure 1: Productivity ranking for an equilibrium with all sourcing modes

Both of these degenerate equilibria still entail a clear productivity ranking, provided that we allow for industry-specific fixed effects which now control for variations in the headquarter-elasticity and variations in the degree of foreign cost advantage. As an extreme case, by adding the two lines of reasoning behind these degenerate equilibria, we might even envisage a complete dominance of foreign integration. While not being in contradiction with the model, an 
industry of this type would simply not contribute any variation that could be used to empirically establish any "sourcing-premia".

Finally, we may allow for a modification in the fixed cost ranking, such that $F^{F I}>F^{D I}>$ $F^{F O}>F^{D O}$. Notice that this still preserves the fundamental idea of an extra fixed cost deriving from executing property rights, as well as the idea of a fixed cost of offshoring within a given organizational mode. It might be tempting to argue, by looking at figure 1, that this just removes the domestic integration strategy. But this is not the case, since there is no fundamental reason within our model that forces us to assume, as we do in figure 1, that the profit line for domestic integration is flatter than the profit line for foreign outsourcing. We should thus not expect from the fundamental premises of the model to observe the productivity ranking depicted in figure 1 . Observing domestic integration to be chosen by more productive firms than foreign outsourcing is perfectly consistent with the model. This is an important qualification for the empirical analysis of "sourcing-premia" below.

This completes our theoretical view of the hold-up problem in a firm's global sourcing decision, based on the seminal contribution of Antràs \& Helpman (2004). The next section turns to an empirical analysis based on Spanish firm-level data. Our analysis will focus entirely on the productivity-sourcing-nexus, treating the "headquarter-elasticity effect" through industry-fixed-effects. The advantage of such a procedure is that it eschews the problem of finding a valid empirical measure of this elasticity. The literature often uses the capital-intensity or skill-intensity of production as a proxy. ${ }^{7}$ But it clearly transpires from the above analysis that factor intensities may capture an entirely different channel, viz. the extent of the foreign cost advantage. We therefore chose to follow a procedure that avoids this problem altogether.

\section{Data}

Our empirical analysis is based on the Spanish "Survey on Business Strategies" (ESEE) ${ }^{8}$ from the Fundación SEPI ${ }^{9}$. The Fundación SEPI surveys approximately 2,000 firms with ten or more employees from all over Spain on a yearly basis since 1990 and addresses strategic business issues, as well as revenue and balance sheet statistics. The sample covers approximately 70 percent of all

\footnotetext{
${ }^{7}$ See Antràs (2003), Yeaple (2006), and Nunn \& Trefler (2008).

8 "Encuesta sobre Estrategias Empresariales".

"'Sociedad Estatal de Participaciones Industriales".
} 
Spanish manufacturing firms with more than 200 employees, plus 5 percent of all firms with a number of employees between 10 and 200. ${ }^{10}$ The coverage of firms is representative for each of the two firm size categories, and special care has been taken to control for the time dynamics in the panel which result from firms exiting and entering markets. ${ }^{11}$

There are three primary advantages associated with the use of this data compared to prior empirical research. First, we know for each firm whether it acquires intermediate inputs through each of the four sourcing strategies (foreign integration, foreign outsourcing, domestic integration, and domestic outsourcing). In the survey, intermediate inputs are defined as goods that have been acquired from a different legal entity (either related or unrelated to the firm) and "incorporated and transformed in the production process". This perfectly fits into the Antràs \& Helpman (2004) modeling setup. ${ }^{12}$ Clearly, the simultaneous and coherent coverage of all four sourcing modes generates a much more comprehensive picture of global sourcing decisions than was the case with earlier studies. ${ }^{13}$ Second, the data allow us to compute several common measures of firm productivity. We can thus evaluate the robustness of our findings in a convincing manner. This is an important point, since previous research has shown that empirical results are often sensitive to the specific way in which productivity is defined and/or estimated. Third, all firms in the sample are categorized by the degree of participation of other companies in a firm's joint capital. We use this information to construct a subsample of firms that satisfy the crucial assumption that the input-supplier never has a controlling stake in the headquarter's capital. ${ }^{14}$ In other words, our firms do have complete discretion over the organizational mode of sourcing.

Table 1 presents the absolute numbers and the percentages of firms with different sourcing strategies in the year 2007. We distinguish between foreign integration $(F I)$, foreign outsourcing $(F O)$, domestic integration (DI), and domestic outsourcing ( $D O)$, as well as all possible combinations thereof. This distinction implies that sourcing categories are mutually exclusive in the

\footnotetext{
${ }^{10}$ Small-sized firms have been selected by a stratified sampling procedure.

${ }^{11}$ For a comprehensive data description see http://www. funep.es/esee/en/einfo_que_es.asp.

${ }^{12}$ We again emphasize that the modeling framework does not envisage a situation in which there is a command hierarchy in the strict sense of the word between firm and input producer.

${ }^{13}$ In principle, our data set covers the years 2000-2007 but we can distinguish the four strategic options for intermediate input sourcing only for the two most recent years. Nonetheless, we take the whole panel into account where its use provides us with additional insights or more accurate estimates (for example, we rely on the whole panel data set when it comes to total factor productivity estimation).

${ }^{14}$ Note also that all data refer to a specific legal entity and not to a corporate group comprising a number of economically interdependent entities.
} 
sense that each firm is assigned to exactly one specific (though potentially mixed) sourcing strategy. Close to 50 percent of the firms in our sample engage in two or more sourcing modes simultaneously. Looking at large firms only, we find an even more telling picture: almost 80 percent of all firms with more than 200 employees make use of such complex sourcing strategies. Strictly speaking, a combinatory use of sourcing channels is ruled out in Antràs (2003) and Antràs \& Helpman (2004), where each firm is assumed to buy a single specific manufacturing component, for which there is a unique optimal sourcing strategy. In our sample, however, only 2.7 percent of firms pursue pure sourcing strategies other than domestic outsourcing. To give an example, the overwhelming majority (more than 98 percent) of all foreign-integration-firms take advantage of at least one additional type of sourcing channel. Therefore, and with an eye on the subsequent econometric analysis, the notion of complex strategies is highly relevant. We also find that nearly half of the firms are active in foreign sourcing in the sense that they do engage in either vertical FDI or offshore outsourcing, or both. By way of comparison, the equivalent percentage number for Japan's manufacturing firms is five percent; see Tomiura (2007). The high share of international firms in Spain seems to reflect the high degree of economic integration in Europe. ${ }^{15}$ Indeed, more than 70 percent of the total value of imported goods have a member country of the European Union as origin, but only five percent come from Latin America. ${ }^{16}$

Table 1: Firms' Sourcing Strategies in 2007

\begin{tabular}{|c|c|c|c|c|c|c|c|c|c|c|c|c|c|c|}
\hline \multicolumn{15}{|c|}{ Large firms (> 200 employees) } \\
\hline$D O$ & $D I$ & $F O$ & $F I$ & $D O D I$ & DOFO & DOFI & DODIFO & DODIFI & DOFOFI & DIFO & $D I F I$ & DIFOFI & FOFI & DODIFOFI \\
\hline 97 & 8 & 14 & 3 & 45 & 144 & 12 & 68 & 8 & 73 & 2 & 0 & 5 & 4 & 50 \\
\hline 17.7 & 1.5 & 2.6 & 0.5 & 8.2 & 26.3 & 2.2 & 12.4 & 1.5 & 13.3 & 0.4 & 0.0 & 0.9 & 0.7 & 9.1 \\
\hline
\end{tabular}

Small firms (<201 employees)

\begin{tabular}{|c|c|c|c|c|c|c|c|c|c|c|c|c|c|c|}
\hline DO & $D I$ & $F O$ & $F I$ & $D O D I$ & DOFO & DOFI & DODIFO & DODIFI & DOFOFI & DIFO & DIFI & DIFOFI & $F O F I$ & DODIFOFI \\
\hline 809 & 9 & 19 & 1 & 50 & 389 & 9 & 46 & 2 & 23 & 0 & 0 & 0 & 1 & 11 \\
\hline 56.3 & 0.6 & 1.3 & 0.1 & 3.7 & 28.4 & 0.7 & 3.4 & 0.1 & 1.7 & 0.0 & 0.0 & 0.0 & 0.1 & 0.8 \\
\hline
\end{tabular}

Sample firms

\begin{tabular}{|c|c|c|c|c|c|c|c|c|c|c|c|c|c|c|}
\hline$D O$ & $D I$ & $F O$ & $F I$ & $D O D I$ & DOFO & $D O F I$ & DODIFO & DODIFI & DOFOFI & DIFO & DIFI & DIFOFI & FOFI & DODIFOFI \\
\hline 906 & 17 & 33 & 4 & 95 & 533 & 21 & 114 & 10 & 96 & 2 & 0 & 5 & 5 & 61 \\
\hline 45.7 & 0.9 & 1.7 & 0.2 & 4.8 & 26.9 & 1.1 & 5.7 & 0.5 & 4.8 & 0.1 & 0.0 & 0.3 & 0.3 & 3.1 \\
\hline
\end{tabular}

Note: In each subtable the middle row and the last row give the numbers and the percentages of firms in the various sourcing categories, respectively. All percentages are of the total number of firms in the respective size category in the 2007 sample ( $N=548$ for large firms, $N=1,436$ for small firms, and $\mathrm{N}=1,984$ for the whole 2007 sample). We represent foreign integration (FI), foreign outsourcing $(F O)$, domestic integration $(D I)$, and domestic outsourcing $(D O)$, as well as all combinations thereof.

\footnotetext{
${ }^{15}$ Admittedly, the number is somewhat overstated since large firms are overrepresented in the sample. Still, the difference is impressive even when looking at small firms only.

${ }^{16}$ These numbers correspond to imports in 2006.
} 
In table 2 we assign firms to groups $D O, D I, F O$, and FI in a mutually inclusive way such that a single firm may appear in more than one category. Integration as opposed to outsourcing of intermediate input suppliers is reserved for only a minority of firms. 304 firms (15 percent) procure intermediate inputs from related parties in Spain, 202 firms (10 percent) acquire them from related parties abroad. By contrast, nearly all firms outsource part of their production to independent suppliers in the domestic economy, and more than 40 percent do so in the foreign economy. Another important observation is that in 2007 (2006) there is a small fraction of around four (six) percent of firms that do not report purchasing any intermediate inputs at all. These firms appear to manufacture and combine all inputs necessary for final goods production within their own legal entity's command structure. In terms of our model, such firms are able to avoid any "hold-up" problem of the type considered above, and to achieve efficient investment levels in all inputs. On the other hand, they also forego the option to arbitrage on factor price differences across countries. We shall address this issue further, when discussing our empirical results in the next section.

Table 2: Firms in Mutually Inclusive Sourcing Categories in 2007

\begin{tabular}{|c|c|c|c|c|c|c|}
\hline & \multicolumn{2}{|c|}{ Large firms (> 200 employees) } & \multicolumn{2}{|c|}{ Small firms (<201 employees) } & \multicolumn{2}{|c|}{ Sample firms } \\
\hline & Number & in $\%$ & Number & in $\%$ & Number & in $\%$ \\
\hline Domestic Outsourcing & 497 & 90.7 & 1,339 & 93.2 & 1,836 & 92.5 \\
\hline Domestic Integration & 186 & 33.9 & 118 & 8.2 & 304 & 15.3 \\
\hline Foreign Outsourcing & 360 & 65.7 & 489 & 34.1 & 849 & 42.8 \\
\hline Foreign Integration & 155 & 28.3 & 47 & 3.3 & 202 & 10.2 \\
\hline Non-Sourcing & 15 & 2.7 & 67 & 4.7 & 82 & 4.1 \\
\hline
\end{tabular}

Note: With mutually inclusive strategies, a single firm may show up in more than one sourcing category. All percentages are of the total number of firms in the respective size category in the 2007 sample ( $N=548$ for large firms, $N=1,436$ for small firms, and $N=1,984$ for the whole 2007 sample).

The disaggregation into large and small firms in table 2 reveals at least two interesting regularities. On the one hand, sourcing inputs from a vertically integrated supplier is a much more common strategy for large firms than for small firms. In fact, one third of firms with more than 200 employees are domestic-integration-firms, and close to 30 percent are foreign-integration-firms. The corresponding numbers for small firms are eight and three percent, respectively. On the other hand, large firms are on average much more present in international sourcing markets than small firms which is very much in line with earlier evidence on export markets. Both observations taken together provide us with a clear hint as regards the fixed cost ranking of global sourcing strategies. Since high fixed costs constitute an especially high hurdle for smaller firms, the Spanish data point towards a ranking that satisfies $F^{F I}>F^{F O}$ and $F^{D I}>F^{D O}$ as well as $F^{D \kappa}>F^{D \kappa}$, as assumed in Antràs \& Helpman (2004). 


\section{Empirical analysis}

As we have detailed in the theoretical section, the Antràs \& Helpman (2004) model suggests that firms who face a hold-up problem in sourcing select themselves into different sourcing strategies, depending on their productivity level and certain structural characteristics of the underlying production relationship. In this section, we want to examine whether our data lend empirical support to the hypothesized productivity ranking. We proceed in two steps. First, we apply a non-parametric test based on the principle of first order stochastic dominance, in order to compare cumulative productivity distributions for certain groups of firms that differ in their sourcing behavior. To be more precise, we test for dominance among the two groups of firms that choose different organizational forms, viz. outsourcing and vertical integration. We do so separately for the domestic sourcing and for offshoring. We also test for stochastic dominance among the two groups that differ in sourcing domestically or offshore, whatever the organizational form. In the second step, we adopt the Bernard \& Jensen (1999) methodology, which has seen extensive use in estimation productivityand size-premia of exporting relative to non-exporting firms. We modify this approach so that it allows us to estimate productivity-premia for firms engaging in different sourcing modes (relative to a baseline category) in a unified econometric framework.

Throughout our analysis, we use four different measures of firm productivity $\theta$, in order to evaluate the sensitivity of our results with respect to different specifications of productivity. The specifications chosen are labor productivity $\left(P R O D_{L}\right)$ computed as valued added per hour worked and three different measures of total factor productivity computed from estimations of sectoral production functions. The first uses standard ordinary least squares (OLS) regressions, the second uses a fixed-effects model, and the third employs the Olley \& Pakes (1996) framework. We denote these measures as $P R O D_{O L S}, P R O D_{F E}$, and $P R O D_{O P}$, respectively. ${ }^{17}$ We treat $P R O D_{O P}$ as the preferred measure since the Olley \& Pakes (1996) method controls for endogeneity problems that may arise from unobserved productivity shocks and/or firms' market exit decisions. Our results are assuringly robust to the use of different productivity measures. We report results only for PROD $_{O P}{ }^{18}$

The entire empirical analysis is conducted relying on two types of samples. The first is restricted

\footnotetext{
17 See appendix for details.

18 All other results are available from the authors upon request.
} 
to true headquarter firms, meaning that we exclude a firm if some other company owns more than 50 percent of the firm's capital and/or if the firm is subject to foreign ownership. ${ }^{19}$ As we have already pointed out in section two, restricting the sample along this dimension is important, in order to ensure that we only observe firms with full discretion over their sourcing strategies. The second is the unrestricted sample, which has the advantage of a larger number of observations, but risks including firms whose sourcing strategy is dictated by their parental company. If we obtain differing results, this is an indication that controlling for true headquarter-status, which to the best of our knowledge is a unique feature of our analysis relative to existing literature, is empirically important. $^{20}$

\subsection{Evidence from a non-parametric test}

In this subsection we employ a non-parametric approach to evaluate the productivity ranking hypothesized in section two. For this purpose we plot empirical cumulative distribution functions for estimates of total factor productivity for firms belonging to different sourcing groups. Suppose we compare two cumulative distribution functions $F(z)$ and $G(z)$, each of which represents the productivity distribution of one sourcing mode. We say that $F(z)$ stochastically dominates $G(z)$ at first order, if $F(z)-G(z) \leq 0 \forall z \in \mathbb{R}$ and $\exists z \in \mathbb{R}$ with $F(z)-G(z)<0$. Computing the distribution free Kolmogorov-Smirnov test statistic (K-S test), we can then conclude a) whether or not the two groups share the same underlying productivity distribution (two-sided test) and b) whether or not the distribution of one group dominates the other (one-sided test). Formally, we test the following hypotheses:

(i) The two-sided test we are interested in is whether

$$
H_{0}: F(z)-G(z)=0 \forall z \in \mathbb{R} \text { against } H_{1}: \exists z \in \mathbb{R} \text { with } F(z)-G(z) \neq 0
$$

can be rejected.

(ii) The one-sided test is to see if it is true that

$$
H_{0}: F(z)-G(z) \leq 0 \forall z \in \mathbb{R} \text { against } H_{1}: \exists z \in \mathbb{R} \text { with } F(z)-G(z)>0
$$

cannot be rejected.

\footnotetext{
19 The threshold value of control is not decisive. For example, in 2007 we exclude roughly 30 percent of the total number of firms $(\mathrm{N}=1,984)$. Reducing the threshold value to 25 percent would eliminate only a slightly larger number of firms but leave any of our results unchanged.

${ }^{20}$ It should be noted that restricting the sample along the ownership dimension significantly decreases the share of large firms in the sample.
} 
The K-S test uses the maximum vertical distance between the curves of two cumulated distribution functions as the statistic $D$, which makes it a particularly robust and useful test whenever the true distributions are unknown.
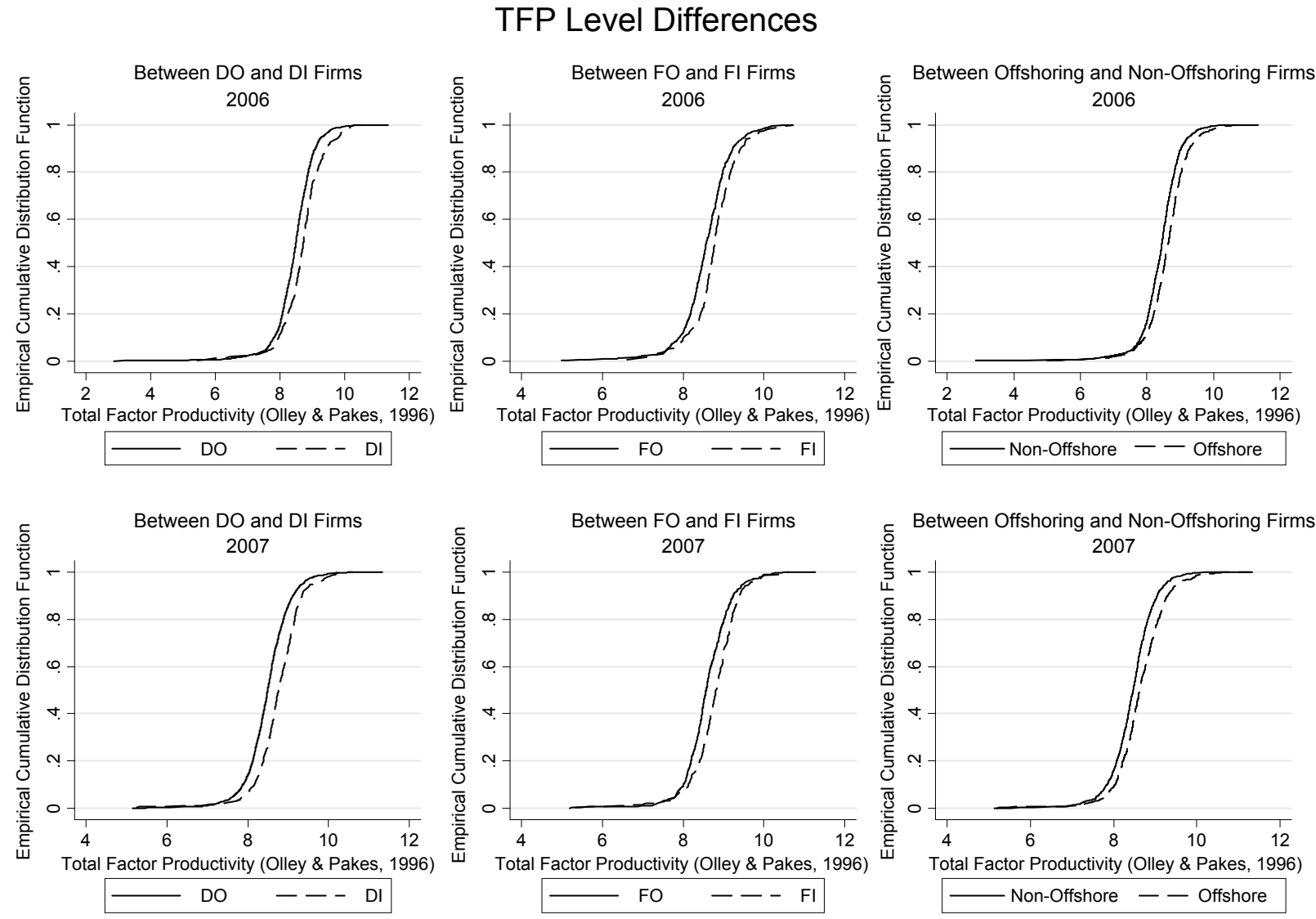

In figure 2 we display the cumulative distribution functions for 2006 and 2007 separately since the K-S testing procedure assumes independence across observations. ${ }^{21}$ Each panel depicts two functions, each representing a distinct sourcing strategy, as indicated in the legend. For a firm to be assigned to a specific sourcing category, we require that it obtains some intermediate inputs through the respective sourcing mode. ${ }^{22}$ Any firm that uses both of the two strategies considered is assigned to the group for which our maintained hypothesis implies a higher fixed cost; see section two above.

\footnotetext{
${ }^{21}$ We only show distribution functions from the unrestricted sample since there are no qualitative differences when using the restricted sample instead. Also, results from the K-S testing procedure are qualitatively identical.

${ }^{22}$ Thus, we completely disregard non-sourcing firms in this subsection.
} 
The samples do not exclude firms that are additionally active in any other sourcing mode. ${ }^{23}$ The graphs suggest a first order stochastic dominance the productivity distribution for integration over that of outsourcing and for offshoring over domestic sourcing of inputs. This is as expected from theory.

The formal test for stochastic dominance using the K-S procedure confirms what the figures suggest. The null hypothesis of the two-sided test under which the samples are drawn from the same distribution has to be rejected in all cases; see table 3. Furthermore, we can never reject the null hypothesis of the one-sided test where we evaluate whether or not integration dominates outsourcing and whether or not offshoring dominates domestic sourcing. By way of contrast, we always have to reject the null hypothesis when performing the one-sided test with sourcing group categories reversed. ${ }^{24}$

Table 3: Kolmogorov-Smirnov Testing Procedure with Total Factor Productivity

\begin{tabular}{|c|c|c|c|c|}
\hline & \multicolumn{2}{|c|}{2006} & \multicolumn{2}{|c|}{2007} \\
\hline & $\begin{array}{l}\text { Maximum } \\
\text { Vertical Distance }\end{array}$ & P-value & $\begin{array}{l}\text { Maximum } \\
\text { Vertical Distance }\end{array}$ & P-value \\
\hline$P R O D_{O P}^{D O}>P R O D_{O P}^{D I}$ & 0.2161 & 0.000 & 0.2629 & 0.000 \\
\hline$P R O D_{O P}^{D O}<P R O D_{O P}^{D I}$ & -0.0094 & 0.957 & -0.0053 & 0.986 \\
\hline Two-Sided Test & 0.2161 & 0.000 & 0.2629 & 0.000 \\
\hline$P R O D_{O P}^{F O}>P R O D_{O P}^{F I}$ & 0.2196 & 0.000 & 0.2252 & 0.000 \\
\hline$P R O D_{O P}^{F O}<P R O D_{O P}^{F I}$ & -0.0011 & 1.000 & -0.0110 & 0.963 \\
\hline Two-Sided Test & 0.2196 & 0.000 & 0.2252 & 0.000 \\
\hline$P R O D_{O P}^{D}>P R O D_{O P}^{F}$ & 0.1795 & 0.000 & 0.1708 & 0.000 \\
\hline$P R O D_{O P}^{D}<P R O D_{O P}^{F}$ & -0.0009 & 0.999 & -0.0039 & 0.985 \\
\hline Two-Sided Test & 0.1795 & 0.000 & 0.1708 & 0.000 \\
\hline
\end{tabular}

Note: Column one gives the null hypotheses to be tested. Two-Sided Test stands for the null hypothesis that the two considered samples come from the same distribution. Columns two and four provide the maximum vertical distance between the two cumulative distribution functions. Vertical arrangement of test results congruent with horizontal arrangement of subfigures in figure 2.

What do we learn from this first stage of our empirical analysis? We draw two main conclusions. First, there are significant productivity differentials between firms that choose a strategy of vertical integration and those that go for outsourcing. The productivity distribution for

\footnotetext{
${ }^{23}$ This is no decisive condition. We redo the whole exercise excluding all firms that are additionally sourcing through other modes but the results remain basically unchanged.

${ }^{24}$ Since the sampling properties of our data vary depending on whether firms have more than 200 employees or not, we are worried about the possibility that the results might not generalize to the Spanish manufacturing industry as a whole. Therefore, we repeat the entire procedure for the two size categories separately. We find that our results are strongly confirmed for small-size firms, while there are some ambiguities as regards very large firms. The true productivity distribution of Spanish manufacturing firms could then be obtained by weighting the two distributions according to their appearance in the Spanish universe of manufacturing firms. Since the small-size firms are underrepresented in our sample, we argue that our findings may be generalized without any further concerns.
} 
the first group of firms features clear stochastic dominance over the second. Notably, this statement holds true for both, the domestic and the foreign sourcing markets, as suggested by theory. Second, as regards the locational choice of intermediate input production, we find clear-cut evidence in favor of the idea that offshoring requires a higher productivity than domestic sourcing. Again, this result is in line with our theoretical model.

\subsection{Estimating sourcing premia}

In this subsection we estimate productivity premia for firms in different sourcing groups using a regression framework borrowed from Bernard \& Jensen (1999). We regress a firm's productivity level on binary variables that indicate a firm's specific sourcing strategy. In the theoretical model of section two, firms face a quaternary choice of intermediate input production where the unique profit-maximizing strategy is either foreign integration $(F I)$, or foreign outsourcing $(F O)$, or domestic integration $(D I)$, or domestic outsourcing $(D O)$. In the subsequent regression analysis, we capture this idea by computing "sourcing dummies" in a hierarchical and mutually exclusive way. If a firm is active in two or more sourcing modes, we assign it to the category which, according to our maintained hypothesis, is associated with the highest fixed cost. In an alternative specification, we depart from this approach and construct the sourcing indicators in a mutually inclusive way. For example, the dummies for $F I$ and $F O$ both take on a value of one, and the dummies for $D I$ and DO a value of zero, if a firm engages in both vertical FDI and offshore outsourcing, but not in domestic sourcing. We thus allow for more flexibility in the estimation procedure, in order to detect differences to the former, more restrictive coding structure that satisfies mutual exclusion.

Formally, we estimate the following panel model:

$$
y_{i t}=\mathbf{x}_{\mathrm{it}} \lambda+u_{i t}, \quad i=1, \ldots, N, \quad t=1, \ldots, T,
$$

where $\quad u_{i t}=c_{i}+\varepsilon_{i t}$.

In this expression, $y_{i t}$ is the dependent variable for firm $i$ at time $t, \mathbf{x}_{i t}=\left(1, x_{i t 2}, \ldots, x_{i t k}\right)$ is a vector of explanatory variables, $\lambda=\left(\lambda_{1}, \lambda_{2}, \ldots, \lambda_{k}\right)^{\prime}$ is a vector of parameters to estimate (including an intercept), and $u_{i t}$ is a composite error term including an unobserved firm-effect $c_{i}$ and an idiosyncratic error $\varepsilon_{i t}$.

We implement three estimation methods. The first simply pools the data and applies ordinary least squares (OLS). This estimator yields consistent estimates, as long as there is no systematic 
contemporaneous correlation between the composite error term and the explanatory variables. To take into account serial correlation within panel units arising from the unobserved firm-level effect $c_{i}$, we always report robust standard errors clustered by firm. Second, we average all variables across the two time periods and apply OLS, whereby we again disregard the time-variation in the data. ${ }^{25}$ This estimator is called the "between-estimator" in the literature. The model reads as

$$
\bar{y}=\overline{\mathbf{x}}_{i} \lambda+\bar{u}_{i}, \quad i=1, \ldots, N,
$$

where

$$
\bar{u}_{i}=c_{i}+\varepsilon_{i}
$$

Bars indicate mean values over time. For this model to deliver consistent estimates, the variables in $\mathbf{x}_{i t}$ need to be strictly exogenous, conditional on $c_{i}$, and $\mathbf{x}_{i t}$ has to be independent from $c_{i}$. The third estimation method explicitly treats the data as a panel and controls for unobserved heterogeneity across firms by estimating a random-effects model. Under the same assumptions as before, this is an efficient estimator.

Our theoretical analysis in section two highlights the interplay between firm-specific productivity $\theta$ and industry-specific headquarter-elasticity $\eta$ in shaping firms' global sourcing decisions. Obviously, this interaction implies that the productivity premia may differ across industries, provided that industries feature different $\eta$-values. Since our purpose here is not to provide a sector-by-sector assessment of performance premia, we control for sector-specific "headquarter-elasticity effects" by including industry-dummies in all of our regressions. ${ }^{26}$ From previous research we must expect that there is a productivity premium also on exporting; see Bernard et al. (2007). To control for this, we additionally incorporate a firm's export status (EXPORT) in our set of regressors. Otherwise, we would be liable to observe spurious positive correlation between foreign sourcing modes and productivity. This could happen, for instance, if firms obtain access to new information through exporting, and if that information reduces the fixed cost of offshoring. Furthermore, we follow the empirical literature on productivity premia in including a firm's age $(A G E)$ and size in terms of employees (SIZE) as control variables. From established theory, we expect a positive sign on the size coefficient. Where feasible, we always include a year dummy in our regressions, in order to isolate our estimates from any year-specific effects.

\footnotetext{
${ }^{25}$ Note again that we observe the sourcing strategies for the years 2006 and 2007 only.

${ }^{26}$ As we have shown in section two, the productivity ranking also depends on a certain fixed cost ranking, which further reinforces the use of industry-specific fixed effects.
} 
As we have mentioned before, our sample includes observations where firms report not to source any inputs outside their own hierarchical control. For both of our coding rules, these firms should be assigned zero values for all indicator variables for sourcing. Strictly speaking, the global sourcing model of section two is silent on why such firms should exist. It assumes at the outset that generating revenue requires two different agents to be involved in the production relationship. We tackle this problem in two ways. First, we exclude all "non-sourcing firms" from the sample and estimate all productivity premia relative to the baseline category of domestic outsourcing. Our model suggests a productivity-dependent sorting pattern such that only the most productive firms source through vertical integration of a foreign input-supplier, and only the least productive firms outsource intermediate input production in the domestic economy. Moreover, firms that outsource the input to a foreign supplier are expected to feature a higher productivity level than firms pursuing vertical integration of a domestic supplier. Under the fixed cost ordering hypothesized in section two, we thus expect the following coefficient ranking for our three indicator variables: $F I>F O>$ $D I$. The second strategy is to include indicator variables for all four sourcing modes in the regression and treat the "non-sourcing firm" as the baseline category, where we have no ex-ante view on the productivity level of non-sourcing firms relative to the other modes. In this case, the coefficient ranking is expected to satisfy $F I>F O>D I>D O$.

Tables 4 and 5 present the first set of results for total factor productivity premia, based on the restricted sample of true headquarter firms. We summarize the most relevant results as follows. First, we find the hypothesized ranking of coefficients in the overwhelming majority of cases. Notice that the ranking is preserved when firm size is controlled for. Among the indicator variables, foreign integration consistently exhibits the largest of all coefficients, and it is always significantly different from zero. The results indicate that firms sourcing through vertical integration of a foreign supplier are roughly 50 percent more productive than firms who source through an independent domestic supplier, assuming that firm size does not play a role. ${ }^{27}$ Second, firms engaged in domestic outsourcing are consistently revealed as the least productive of all. In table 4, all coefficients of all other sourcing-dummies are positive and mostly significant, while in table 5 the dummy for domestic outsourcing is the only sourcing indicator with a negative coefficient. Translating our regression coefficients into magnitudes of premia, we recognize that firms engaged in foreign outsourcing are somewhat above 20 percent more productive than those who do so in the

\footnotetext{
${ }^{27}$ The premia are calculated from the coefficients as follows: PREMIUM ${ }^{\ell \kappa}=100 \times\left[\exp \left(\lambda^{\ell \kappa}\right)-1\right]$
} 
home economy. For domestic integration the premium is somewhat below 20 percent. ${ }^{28}$ Third, we do not find a statistically significant difference between firms who choose a strategy of foreign outsourcing and those who source through domestic vertical integration, although the point estimates of the coefficients for $F O$ and $D I$ do suggest that the former are more productive than the latter. Generally speaking, our regressions elucidate important structural differences in the productivity levels of firms depending on their sourcing channels, and these differences are impressively consistent with the model of global sourcing introduced by Antràs \& Helpman (2004).

Table 4: Total Factor Productivity Premia (Mutually Exclusive Sourcing Dummies, Non-Sourcing Firms Excluded)

\begin{tabular}{|c|c|c|c|c|c|c|c|c|c|}
\hline \multirow[b]{2}{*}{ VARIABLES } & \multicolumn{3}{|c|}{ Pooled OLS } & \multicolumn{3}{|c|}{ Between Estimator } & \multicolumn{3}{|c|}{ Random Effects } \\
\hline & (1) & $(2)$ & (3) & (4) & (5) & (6) & (7) & (8) & (9) \\
\hline$F I$ & $\begin{array}{l}0.447^{* * *} \\
(0.107)\end{array}$ & $\begin{array}{l}0.403 * * * \\
(0.109)\end{array}$ & $\begin{array}{l}0.236^{* *} \\
(0.105)\end{array}$ & $\begin{array}{l}0.532^{* * *} \\
(0.131)\end{array}$ & $\begin{array}{l}0.484 * * * \\
(0.133)\end{array}$ & $\begin{array}{l}0.295^{* *} \\
(0.134)\end{array}$ & $\begin{array}{l}0.371 * * * \\
(0.089)\end{array}$ & $\begin{array}{l}0.324^{* * *} \\
(0.091)\end{array}$ & $\begin{array}{l}0.192 * * \\
(0.085)\end{array}$ \\
\hline FO & $\begin{array}{l}0.192^{* * *} \\
(0.027)\end{array}$ & $\begin{array}{l}0.163 * * * \\
(0.030)\end{array}$ & $\begin{array}{l}0.118^{* * *} \\
(0.029)\end{array}$ & $\begin{array}{l}0.224^{* * *} \\
(0.032)\end{array}$ & $\begin{array}{l}0.192^{* * *} \\
(0.035)\end{array}$ & $\begin{array}{l}0.142^{* * *} \\
(0.035)\end{array}$ & $\begin{array}{l}0.145 * * * \\
(0.027)\end{array}$ & $\begin{array}{l}0.117^{* * *} \\
(0.029)\end{array}$ & $\begin{array}{l}0.081 * * * \\
(0.029)\end{array}$ \\
\hline$D I$ & $\begin{array}{l}0.177^{* *} \\
(0.073)\end{array}$ & $\begin{array}{l}0.171^{* *} \\
(0.074)\end{array}$ & $\begin{array}{l}0.076 \\
(0.076)\end{array}$ & $\begin{array}{l}0.177^{* *} \\
(0.081)\end{array}$ & $\begin{array}{l}0.170^{* *} \\
(0.081)\end{array}$ & $\begin{array}{l}0.059 \\
(0.082)\end{array}$ & $\begin{array}{l}0.118^{*} \\
(0.065)\end{array}$ & $\begin{array}{l}0.110^{*} \\
(0.065)\end{array}$ & $\begin{array}{l}0.040 \\
(0.067)\end{array}$ \\
\hline Age & & $\begin{array}{l}-0.000 \\
(0.001)\end{array}$ & $\begin{array}{l}-0.002 * * \\
(0.001)\end{array}$ & & $\begin{array}{l}-0.000 \\
(0.001)\end{array}$ & $\begin{array}{l}-0.001 * \\
(0.001)\end{array}$ & & $\begin{array}{l}-0.000 \\
(0.001)\end{array}$ & $\begin{array}{l}-0.001 * \\
(0.001)\end{array}$ \\
\hline Export & & $\begin{array}{l}0.088^{* * *} \\
(0.029)\end{array}$ & $\begin{array}{l}0.030 \\
(0.031)\end{array}$ & & $\begin{array}{l}0.0812 * * \\
(0.032)\end{array}$ & $\begin{array}{l}0.019 \\
(0.033)\end{array}$ & & $\begin{array}{l}0.101^{* * *} \\
(0.028)\end{array}$ & $\begin{array}{l}0.048 \\
(0.030)\end{array}$ \\
\hline Size & & & $\begin{array}{l}0.085^{* * *} \\
(0.014)\end{array}$ & & & $\begin{array}{l}0.086 * * * \\
(0.014)\end{array}$ & & & $\begin{array}{l}0.085^{* * *} \\
(0.014)\end{array}$ \\
\hline Constant & $\begin{array}{l}8.318^{* * *} \\
(0.069)\end{array}$ & $\begin{array}{l}8.286 * * * \\
(0.071)\end{array}$ & $\begin{array}{l}8.009 * * * \\
(0.080)\end{array}$ & $\begin{array}{l}8.280 * * * \\
(0.080)\end{array}$ & $\begin{array}{l}8.248 * * * \\
(0.082)\end{array}$ & $\begin{array}{l}7.973^{* * *} \\
(0.092)\end{array}$ & $\begin{array}{l}8.320 * * * \\
(0.068)\end{array}$ & $\begin{array}{l}8.274^{* * *} \\
(0.070)\end{array}$ & $\begin{array}{l}7.994^{* * *} \\
(0.080)\end{array}$ \\
\hline Industry Fixed Effects & Yes & Yes & Yes & Yes & Yes & Yes & Yes & Yes & Yes \\
\hline Year Fixed Effects & Yes & Yes & Yes & No & No & No & Yes & Yes & Yes \\
\hline$H 0: F I=F O$ & 0.02 & 0.03 & 0.26 & 0.02 & 0.03 & 0.25 & 0.01 & 0.02 & 0.19 \\
\hline$H 0: F I=D I$ & 0.04 & 0.07 & 0.20 & 0.02 & 0.04 & 0.12 & 0.02 & 0.05 & 0.14 \\
\hline$H 0: F O=D I$ & 0.84 & 0.92 & 0.58 & 0.57 & 0.79 & 0.32 & 0.67 & 0.92 & 0.53 \\
\hline Observations & 2474 & 2474 & 2474 & 2474 & 2474 & 2474 & 2474 & 2474 & 2474 \\
\hline$R^{2}$ & 0.14 & 0.14 & 0.17 & 0.16 & 0.17 & 0.19 & 0.16 & 0.16 & 0.19 \\
\hline
\end{tabular}

The table gives estimation results obtained with the Bernard \& Jensen (1999) methodology. Each column represents a separate regression where the dependent variable $P R O D_{O P}$ is a function of dummy variables for foreign integration $(F I)$, foreign outsourcing $(F O)$, domestic integration $(D I)$, and a firm's size in terms of employees $(S I Z E)$, age $(A G E)$, and export status (EXPORT). The sourcing dummies are mutually exclusive. If a firm is active in two or more sourcing modes simultaneously, it is assigned to the category which is supposed to be associated with the highest fixed costs. The sample excludes firms with domestic or foreign parent companies as well as non-sourcing firms. The lower part of the table gives p-values of tests for equality of coefficients. Robust standard errors are clustered by firm (except for the between estimator) and given in parentheses. The size variable is in natural logs. ${ }^{*}, * *, * * *$ indicate significance at the $10 \%, 5 \%, 1 \%$ levels, respectively.

How do things change if we code our indicator variables for the sourcing strategies in a mutually inclusive way? Tables 6 and 7 reveal that the picture changes dramatically. First, the results no longer suggest a robust ranking of sourcing coefficients. Although we can still be confident that firms engaged in domestic outsourcing firms belong to the least productive firms in

28 Again, we are looking at table 3 at the columns where we do not control for size. 
Table 5: Total Factor Productivity Premia (Mutually Exclusive Sourcing Dummies, Non-Sourcing Firms Included)

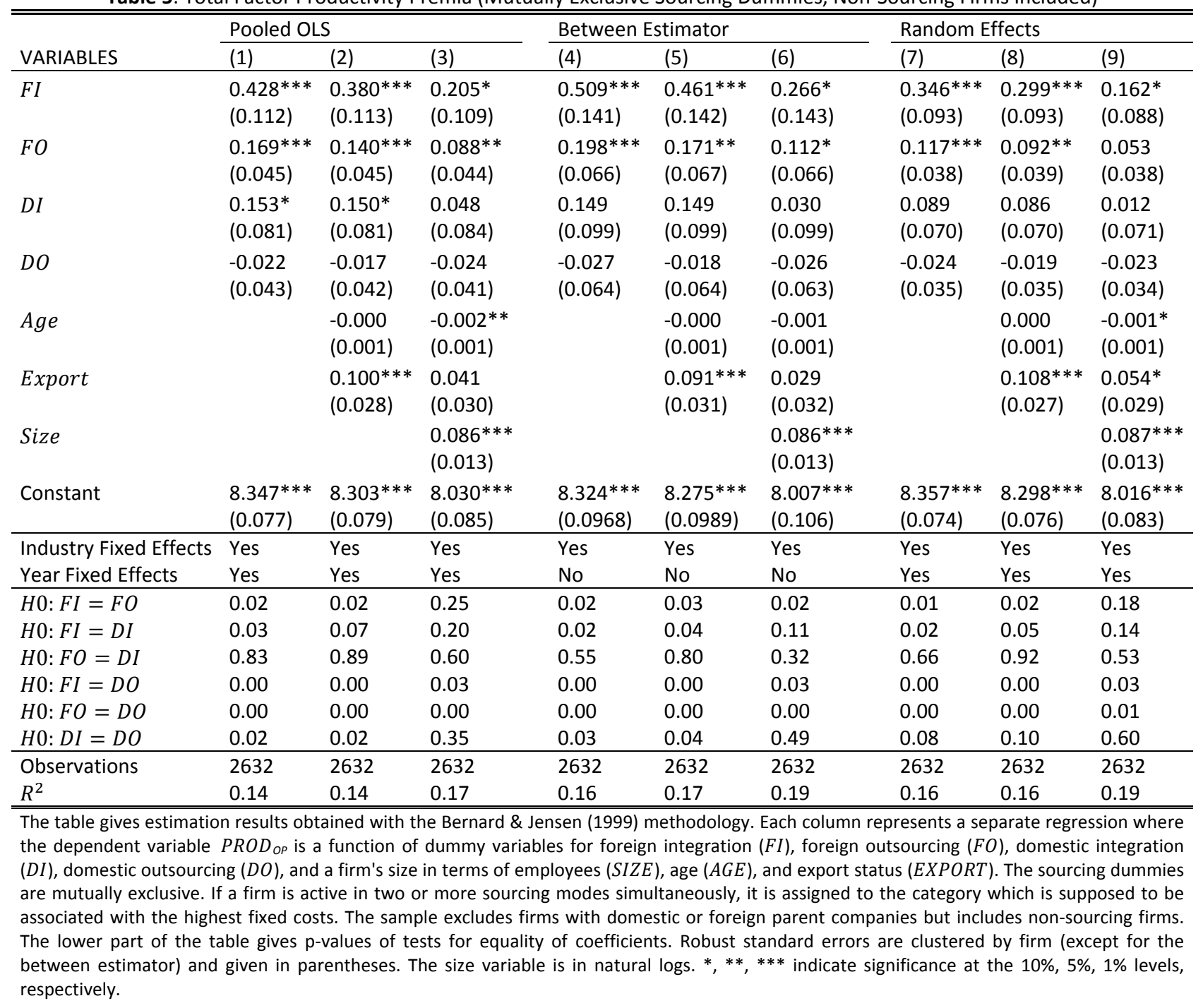

the sample (together with "non-sourcing firms"), we do not find a significant difference between any two of the remaining sourcing coefficients. How does this fit with our earlier results obtained with mutually exclusive sourcing dummies? Strictly speaking, our regressions suggest that any sourcing category contributes equally to a firm's productivity premium, relative to the pure domestic outsourcing (or "non-sourcing") case. For each additional sourcing mode, the productivity premium rises by roughly 20 percentage points when size is not controlled for. Thus, the interpretation seems straightforward: foreign integration per se does not imply that a firm is among the most productive ones. Rather, high productivity premia seem related to the fact that firms simultaneously combine various sourcing channels. This is remarkable in that it points to the need for further refinements to theory, so that it may explain such complex strategies. 
Table 6: Total Factor Productivity Premia (Mutually Inclusive Sourcing Dummies, Non-Sourcing Firms Excluded)

\begin{tabular}{|c|c|c|c|c|c|c|c|c|c|}
\hline \multirow[b]{2}{*}{ VARIABLES } & \multicolumn{3}{|c|}{ Pooled OLS } & \multicolumn{3}{|c|}{ Between Estimator } & \multicolumn{3}{|c|}{ Random Effects } \\
\hline & (1) & (2) & (3) & (4) & (5) & (6) & (7) & (8) & (9) \\
\hline$F I$ & $\begin{array}{l}0.194 * \\
(0.116)\end{array}$ & $\begin{array}{l}0.182 \\
(0.115)\end{array}$ & $\begin{array}{l}0.096 \\
(0.108)\end{array}$ & $\begin{array}{l}0.258^{*} \\
(0.133)\end{array}$ & $\begin{array}{l}0.242 * \\
(0.134)\end{array}$ & $\begin{array}{l}0.144 \\
(0.133)\end{array}$ & $\begin{array}{l}0.197 * * \\
(0.096)\end{array}$ & $\begin{array}{l}0.179 * \\
(0.095)\end{array}$ & $\begin{array}{l}0.102 \\
(0.087)\end{array}$ \\
\hline FO & $\begin{array}{l}0.173 * * * \\
(0.026)\end{array}$ & $\begin{array}{l}0.146 * * * \\
(0.029)\end{array}$ & $\begin{array}{l}0.111^{* * *} \\
(0.028)\end{array}$ & $\begin{array}{l}0.204^{* * *} \\
(0.032)\end{array}$ & $\begin{array}{l}0.174 * * * \\
(0.034)\end{array}$ & $\begin{array}{l}0.133^{* * *} \\
(0.034)\end{array}$ & $\begin{array}{l}0.131 * * * \\
(0.027)\end{array}$ & $\begin{array}{l}0.104^{* * *} \\
(0.029)\end{array}$ & $\begin{array}{l}0.076 * * * \\
(0.028)\end{array}$ \\
\hline$D I$ & $\begin{array}{l}0.196 * * * \\
(0.055)\end{array}$ & $\begin{array}{l}0.193 * * * \\
(0.056)\end{array}$ & $\begin{array}{l}0.097 \\
(0.060)\end{array}$ & $\begin{array}{l}0.174 * * * \\
(0.058)\end{array}$ & $\begin{array}{l}0.170 * * * \\
(0.058)\end{array}$ & $\begin{array}{l}0.064 \\
(0.060)\end{array}$ & $\begin{array}{l}0.164 * * * \\
(0.053)\end{array}$ & $\begin{array}{l}0.159 * * * \\
(0.053)\end{array}$ & $\begin{array}{l}0.078 \\
(0.056)\end{array}$ \\
\hline Age & & $\begin{array}{l}-0.001 \\
(0.001)\end{array}$ & $\begin{array}{l}-0.002 * * \\
(0.001)\end{array}$ & & $\begin{array}{l}-0.000 \\
(0.001)\end{array}$ & $\begin{array}{l}-0.001^{*} \\
(0.001)\end{array}$ & & $\begin{array}{l}-0.000 \\
(0.001)\end{array}$ & $\begin{array}{l}-0.001^{*} \\
(0.001)\end{array}$ \\
\hline Export & & $\begin{array}{l}0.087^{* * *} \\
(0.029)\end{array}$ & $\begin{array}{l}0.033 \\
(0.031)\end{array}$ & & $\begin{array}{l}0.083^{* * *} \\
(0.032)\end{array}$ & $\begin{array}{l}0.022 \\
(0.033)\end{array}$ & & $\begin{array}{l}0.101 * * * \\
(0.028)\end{array}$ & $\begin{array}{l}0.050 * \\
(0.030)\end{array}$ \\
\hline Size & & & $\begin{array}{l}0.081 * * * \\
(0.014)\end{array}$ & & & $\begin{array}{l}0.084 * * * \\
(0.014)\end{array}$ & & & $\begin{array}{l}0.082^{* * *} \\
(0.014)\end{array}$ \\
\hline Constant & $\begin{array}{l}8.298 * * * \\
(0.069)\end{array}$ & $\begin{array}{l}8.269 * * * \\
(0.070)\end{array}$ & $\begin{array}{l}8.013^{* * *} \\
(0.080)\end{array}$ & $\begin{array}{l}8.265^{* * * *} \\
(0.080)\end{array}$ & $\begin{array}{l}8.235^{* * *} \\
(0.082)\end{array}$ & $\begin{array}{l}7.974 * * * \\
(0.092)\end{array}$ & $\begin{array}{l}8.301 * * * \\
(0.068)\end{array}$ & $\begin{array}{l}8.259 * * * \\
(0.070)\end{array}$ & $\begin{array}{l}7.997 * * * \\
(0.080)\end{array}$ \\
\hline Industry Fixed Effects & Yes & Yes & Yes & Yes & Yes & Yes & Yes & Yes & Yes \\
\hline Year Fixed Effects & Yes & Yes & Yes & No & No & No & Yes & Yes & Yes \\
\hline$H 0: F I=F O$ & 0.86 & 0.77 & 0.89 & 0.71 & 0.63 & 0.94 & 0.52 & 0.46 & 0.79 \\
\hline$H 0: F I=D I$ & 0.99 & 0.93 & 0.99 & 0.59 & 0.64 & 0.60 & 0.78 & 0.86 & 0.82 \\
\hline$H 0: F O=D I$ & 0.71 & 0.45 & 0.83 & 0.65 & 0.96 & 0.31 & 0.57 & 0.36 & 0.98 \\
\hline Observations & 2474 & 2474 & 2474 & 2474 & 2474 & 2474 & 2474 & 2474 & 2474 \\
\hline$R^{2}$ & 0.14 & 0.15 & 0.17 & 0.17 & 0.17 & 0.19 & 0.16 & 0.17 & 0.19 \\
\hline
\end{tabular}

The table gives estimation results obtained with the Bernard \& Jensen (1999) methodology. Each column represents a separate regression where the dependent variable $P R O D_{O P}$ is a function of dummy variables for foreign integration $(F I)$, foreign outsourcing $(F O)$, domestic integration $(D I)$, and a firm's size in terms of employees $(S I Z E)$, age $(A G E)$, and export status (EXPORT). The sourcing dummies are mutually inclusive. The sample excludes firms with domestic or foreign parent companies as well as non-sourcing firms. The lower part of the table gives $p$-values of tests for equality of coefficients. Robust standard errors are clustered by firm (except for the between estimator) and given in parentheses. The size variable is in natural logs. $* * *, * * *$ indicate significance at the $10 \%, 5 \%, 1 \%$ levels, respectively.

It is worth noting that the inclusion of firm size affects the coefficients for outsourcing and integration dummies differently. While it takes up all productivity differences of the two integration modes with respect to the baseline categories, the coefficient for $F O$ continues to be highly significant. Apparently, firm size plays a superior role in explaining productivity premia of vertically integrating firms.

In the text, we only report the results for the restricted sample, but we find at least two interesting differences between the estimates with the unrestricted and the restricted samples. ${ }^{29}$ First, the coefficient ranking obtained with mutually exclusive coding of the indicator variables changes slightly once we include "non-headquarter" firms in the sample. Indeed, what we observe is a reversal in the ranking of the coefficients for foreign outsourcing and domestic integration, and this reversal is at least marginally significant in several specifications. This finding is consistent with empirical evidence reported by Federico (2009), who cannot identify true headquarters in his

${ }^{29}$ See the appendix for estimation results with the unrestricted sample. 
sample of Italian manufacturing firms. ${ }^{30}$ Second, all point estimates of the sourcing coefficients are smaller with the unrestricted sample than with the restricted sample, with one exception: The $D I$-dummy features a larger coefficient with the unrestricted sample when "non-sourcing firms" are excluded. Generally, this observation suggests that true headquarter firms have to overcome higher productivity hurdles relative to the domestic outsourcing category than "non-headquarter" firms whose sourcing strategy might not always reflect their own decision, but that of a domestic or foreign parental company.

Table 7: Total Factor Productivity Premia (Mutually Inclusive Sourcing Dummies, Non-Sourcing Firms Included)

\begin{tabular}{|c|c|c|c|c|c|c|c|c|c|}
\hline \multirow[b]{2}{*}{ VARIABLES } & \multicolumn{3}{|c|}{ Pooled OLS } & \multicolumn{3}{|c|}{ Between Estimator } & \multicolumn{3}{|c|}{ Random Effects } \\
\hline & (1) & $(2)$ & (3) & (4) & $(5)$ & (6) & (7) & $(8)$ & (9) \\
\hline$F I$ & $\begin{array}{l}0.198^{*} \\
(0.115)\end{array}$ & $\begin{array}{l}0.182 \\
(0.114)\end{array}$ & $\begin{array}{l}0.095 \\
(0.106)\end{array}$ & $\begin{array}{l}0.262^{* *} \\
(0.132)\end{array}$ & $\begin{array}{l}0.242^{*} \\
(0.132)\end{array}$ & $\begin{array}{l}0.145 \\
(0.131)\end{array}$ & $\begin{array}{l}0.200^{* *} \\
(0.095)\end{array}$ & $\begin{array}{l}0.180 * \\
(0.094)\end{array}$ & $\begin{array}{l}0.101 \\
(0.085)\end{array}$ \\
\hline FO & $\begin{array}{l}0.170 * * * \\
(0.026)\end{array}$ & $\begin{array}{l}0.137^{* * * *} \\
(0.028)\end{array}$ & $\begin{array}{l}0.103 * * * \\
(0.027)\end{array}$ & $\begin{array}{l}0.204^{* * *} \\
(0.032)\end{array}$ & $\begin{array}{l}0.168^{* * *} \\
(0.034)\end{array}$ & $\begin{array}{l}0.128 * * * \\
(0.034)\end{array}$ & $\begin{array}{l}0.124^{* * *} \\
(0.026)\end{array}$ & $\begin{array}{l}0.096^{* * *} \\
(0.028)\end{array}$ & $\begin{array}{l}0.069 * * \\
(0.027)\end{array}$ \\
\hline$D I$ & $\begin{array}{l}0.193 * * * \\
(0.055)\end{array}$ & $\begin{array}{l}0.190^{* * *} \\
(0.055)\end{array}$ & $\begin{array}{l}0.091 \\
(0.059)\end{array}$ & $\begin{array}{l}0.170 * * * \\
(0.057)\end{array}$ & $\begin{array}{l}0.165^{* * *} \\
(0.057)\end{array}$ & $\begin{array}{l}0.059 \\
(0.059)\end{array}$ & $\begin{array}{l}0.161 * * * \\
(0.052)\end{array}$ & $\begin{array}{l}0.155^{* * *} \\
(0.052)\end{array}$ & $\begin{array}{l}0.073 \\
(0.055)\end{array}$ \\
\hline DO & $\begin{array}{l}0.011 \\
(0.037)\end{array}$ & $\begin{array}{l}0.017 \\
(0.037)\end{array}$ & $\begin{array}{l}0.009 \\
(0.036)\end{array}$ & $\begin{array}{l}-0.013 \\
(0.054)\end{array}$ & $\begin{array}{l}-0.003 \\
(0.054)\end{array}$ & $\begin{array}{l}-0.011 \\
(0.054)\end{array}$ & $\begin{array}{l}0.006 \\
(0.032)\end{array}$ & $\begin{array}{l}0.010 \\
(0.031)\end{array}$ & $\begin{array}{l}0.004 \\
(0.031)\end{array}$ \\
\hline Age & & $\begin{array}{l}-0.000 \\
(0.001)\end{array}$ & $\begin{array}{l}-0.002 * * \\
(0.001)\end{array}$ & & $\begin{array}{l}-0.000 \\
(0.001)\end{array}$ & $\begin{array}{l}-0.001 * \\
(0.001)\end{array}$ & & $\begin{array}{l}-0.000 \\
(0.001)\end{array}$ & $\begin{array}{l}-0.001 * \\
(0.001)\end{array}$ \\
\hline Export & & $\begin{array}{l}0.100 * * * \\
(0.028)\end{array}$ & $\begin{array}{l}0.044 \\
(0.030)\end{array}$ & & $\begin{array}{l}0.093 * * * \\
(0.031)\end{array}$ & $\begin{array}{l}0.032 \\
(0.032)\end{array}$ & & $\begin{array}{l}0.109 * * * \\
(0.027)\end{array}$ & $\begin{array}{l}0.057^{* *} \\
(0.029)\end{array}$ \\
\hline Size & & & $\begin{array}{l}0.083 * * * \\
(0.014)\end{array}$ & & & $\begin{array}{l}0.084^{* * *} \\
(0.013)\end{array}$ & & & $\begin{array}{l}0.083^{* * *} \\
(0.014)\end{array}$ \\
\hline Constant & $\begin{array}{l}8.299 * * * \\
(0.075) \\
\end{array}$ & $\begin{array}{l}8.256 * * * \\
(0.077) \\
\end{array}$ & $\begin{array}{l}8.004 * * * \\
(0.083) \\
\end{array}$ & $\begin{array}{l}8.297 * * * \\
(0.091) \\
\end{array}$ & $\begin{array}{l}8.249 * * * \\
(0.094)\end{array}$ & $\begin{array}{l}7.994^{* * *} \\
(0.101)\end{array}$ & $\begin{array}{l}8.312 * * * \\
(0.073) \\
\end{array}$ & $\begin{array}{l}8.257 * * * \\
(0.074) \\
\end{array}$ & $\begin{array}{l}7.996 * * * \\
(0.082) \\
\end{array}$ \\
\hline Industry Fixed Effects & Yes & Yes & Yes & Yes & Yes & Yes & Yes & Yes & Yes \\
\hline Year Fixed Effects & Yes & Yes & Yes & No & No & No & Yes & Yes & Yes \\
\hline$H 0: F I=F O$ & 0.81 & 0.71 & 0.95 & 0.68 & 0.60 & 0.90 & 0.46 & 0.41 & 0.73 \\
\hline$H 0: F I=D I$ & 0.97 & 0.95 & 0.98 & 0.55 & 0.62 & 0.57 & 0.73 & 0.82 & 0.79 \\
\hline$H 0: F O=D I$ & 0.70 & 0.41 & 0.86 & 0.61 & 0.97 & 0.31 & 0.54 & 0.33 & 0.96 \\
\hline$H 0: F I=D O$ & 0.12 & 0.17 & 0.44 & 0.06 & 0.09 & 0.28 & 0.05 & 0.09 & 0.28 \\
\hline$H 0: F O=D O$ & 0.00 & 0.01 & 0.05 & 0.00 & 0.01 & 0.04 & 0.01 & 0.06 & 0.14 \\
\hline$H 0: D I=D O$ & 0.01 & 0.01 & 0.23 & 0.02 & 0.03 & 0.37 & 0.01 & 0.01 & 0.26 \\
\hline Observations & 2632 & 2632 & 2632 & 2632 & 2632 & 2632 & 2632 & 2632 & 2632 \\
\hline$R^{2}$ & 0.14 & 0.15 & 0.17 & 0.16 & 0.17 & 0.19 & 0.16 & 0.17 & 0.19 \\
\hline
\end{tabular}

The table gives estimation results obtained with the Bernard \& Jensen (1999) methodology. Each column represents a separate regression where the dependent variable $P R O D_{O P}$ is a function of dummy variables for foreign integration $(F I)$, foreign outsourcing $(F O)$, domestic integration $(D I)$, domestic outsourcing $(D O)$, and a firm's size in terms of employees (SIZE), age $(A G E)$, and export status (EXPORT). The sourcing dummies are mutually inclusive. The sample excludes firms with domestic or foreign parent companies but includes non-sourcing firms. The lower part of the table gives $p$-values of tests for equality of coefficients. Robust standard errors are clustered by firm (except for the between estimator) and given in parentheses. The size variable is in natural logs. ${ }^{*}, * *, * * *$ indicate significance at the $10 \%, 5 \%, 1 \%$ levels, respectively.

\footnotetext{
${ }^{30}$ It should be noted, however, that this sort of ambiguity in the data can by no means be interpreted as evidence against the model. In fact, a potential reversal in the productivity ranking of $D I$ and $F O$ firms can easily be rationalized within the model by assuming sufficiently high fixed costs for domestic integration compared to foreign outsourcing.
} 


\section{Final remarks}

Recent theoretical developments have helped us understand why firm heterogeneity in productivity might even be a long-run equilibrium phenomenon. Such theoretical models imply that firms with different productivity levels behave differently, even when they face the same market environment. This seems corroborated by a wealth of empirical literature which shows that more productive firms are more likely to actively pursue strategies of internationalization both in generating revenue and sourcing inputs. We now have an impressive body of theory that explains such "globalization premia" through a self-selection of firms into different strategies of internationalization, based on exogenous differences in their productivity.

In this paper, we have presented empirical evidence on such premia, based on a very prominent model of this type developed by Antràs \& Helpman (2004). In this model, firm heterogeneity is determined as in Melitz (2003), and firms face the problem of sourcing their inputs in an environment that is characterized by a hold-up problem due to lack of enforceable contracts. They react to this environment by choosing between two organizational forms of sourcing, viz. outsourcing via arms-length transactions and acquiring property rights in the desired inputs, respectively. In addition, firms face the more familiar choice between domestic and foreign sourcing. Thus, there are four possible strategies, and the model suggests that firms with different productivity levels adopt different strategies. In this paper, we have first examined the interplay between a firm's productivity and other characteristics of production that should determine its sourcing strategy. We have then examined the empirical relevance of the "global sourcing premia" implied by the model, relying on Spanish firm-level data that are uniquely geared towards such an empirical exercise. In doing so, we have used both, non-parametric methods as well as an estimation approach.

We find a productivity ranking across different sourcing strategies which is impressively consistent with the model. Firms who choose vertical integration tend to be more productive than those who rely on arms-length transactions, and firms who source offshore are generally more productive than those who source their inputs domestically. This is in line with the theoretical model, provided that foreign sourcing unambiguously requires larger fixed costs than domestic sources, and that exercising property rights always entails a larger fixed cost than arms-length transactions, as hypothesized by Antràs \& Helpman (2004). We do not offer any independent 
empirical support for this ranking, but the ranking seems very plausible.

We see the following agenda for future research on this issue. First, as regards theoretical modeling, we feel that the model should be generalized so as to generate outcomes where a firm adopts foreign and domestic sourcing strategies as well as different organizational modes at the same time, because this is what we find in the data. A step in this direction has been achieved in Antràs \& Helpman (2008) where the assumption of complete lack of enforceable contracts has been relaxed. In our view, a more general and flexible modeling framework relating to the notion of offshoring and/or vertical integration would constitute further progress.

As regards empirical analysis, a more comprehensive examination of how a firm's sourcing strategy relates to further characteristics of the underlying production relationship would seem important. In particular, the notion of a "headquarter-elasticity" which is a key variable in the model should also be brought into the realm of empirical observations. Our analysis suggests that doing so through empirical measures of capital intensity or skill intensity as a proxy risks confounding strategic issues pertaining to the hold-up problem with cost advantages from offshoring. These two aspects need to be clearly separated, both in the theoretical framework and the empirical analysis. 


\section{References}

[1] Antràs, POL. 2003. "Firms, Contracts, and Trade Structure." The Quarterly Journal of Economics, 118(4): 1375-1418.

[2] Antràs, Pol, And Elhanan Helpman. 2004. "Global Sourcing." Journal of Political Economy, 112(3): 552-580.

[3] Antràs, Pol, And Elhanan Helpman. 2008. "Contractual Frictions and Global Sourcing." In The Organization of Firms in a Global Economy, ed. by Helpman, E., Marin, D., and Verdier, T., Harvard University Press: Cambridge, MA.

[4] Bernard, ANDREW B., AND J. BRAdFord JENSEN. 1999. "Exceptional Exporter Performance: Cause, Effect or Both?" Journal of International Economics, 47(1): 1-25.

[5] Bernard, Andrew B., J. Bradford Jensen, Stephen J. Redding, And Peter K. Schott. 2007. "Firms in International Trade." Journal of Economic Perspectives, Summer 2007.

[6] Federico, Stefano. 2009. "Outsourcing versus integration at home or abroad and firm heterogeneity." Empirica, Online publication date: 2009/12/10.

[7] Greenaway, David, AND Richard KnElLER. 2007. "Firm heterogeneity, exporting and foreign direct investment." Economic Journal, 117(517): F134-F161..

[8] Grossman, Sanford J., AND Oliver D. Hart. 1986. "The Costs and Benefits of Ownership: A Theory of Vertical and Lateral Integration." Journal of Political Economy, 94(4): 691-719.

[9] DefeVer, Fabrice, AND Farid Toubal. 2007. "Productivity and the Sourcing Modes of Multinational Firms: Evidence from French Firm-Level Data.” CEP Discussion Paper No. 842.

[10] Dixit, Avinash K., And Joseph E. Stiglitz. 1977. "Monopolistic Competition and Optimum Product Diversity.” American Economic Review, 67(3): 297-308.

[11] Grossman, Sanford J., And Oliver D. Hart. 1986. "The Costs and Benefits of Ownership: A Theory of Vertical and Lateral Integration." Journal of Political Economy, 94(4): 691-719.

[12] Helpman, Elhanan. 2006. "Trade, FDI, and the Organization of Firms." Journal of Economics Literature, 44(3): 589-630.

[13] Helpman, Elhanan, Marc J. Melitz, and Stephen R. Yeaple. 2004. "Exports versus FDI with Heterogeneous Firms." American Economic Review, 94(1): 300-316.

[14] Melitz, MARC J. 2003. "The Impact of Trade on Intra-Industry Reallocations and Aggregate Industry Productivity." Econometrica, 71(6): 1695-1725.

[15] Nunn, Nathan, And Daniel Trefler. 2008. "The Boundaries of the Multinational Firm: An Empirical Analysis." In The Organization of Firms in a Global Economy, ed. by Helpman, E., Marin, D., and Verdier, T., Harvard University Press: Cambridge, MA.

[16] Olley, S., AND A. PAKES. 1996. "The Dynamics of Productivity in the Telecommunications Equipment Industry.” Econometrica, 64(6): 1263-1298. 
[17] TOMIURA, EIICHI. 2007. "Foreign Outsourcing, exporting, and FDI: A productivity comparison at the firm level." Journal of International Economics, 72(1): 113-127.

[18] Yeaple, Stephen R. 2006. "Offshoring, Foreign Direct Investment, and the Structure of U.S. Trade" Journal of the European Economic Association, 4(2-3): 602-611. 


\section{Appendix}

This appendix gives information on how we compute the different measures of productivity at the level of the firm. Where necessary, we calculate real values in terms of 2007 prices using sectoral price indexes provided by the national statistics institute (INE) in Spain.

Labor productivity. $P R O D_{L}$. Computed as value added divided by the approximation of hours effectively worked. The units of the hourly productivity may be interpreted as Euros per hour. This variable is calculated only for companies with non-negative values added. Value added is defined as the sum of sales, changes in the stock of inventory, and other operating income minus the sum of purchases and the costs of external services.

Total factor productivity. $P R O D_{O L S}$. Computed as the residual of sectoral production function estimates according to the following regression equation (estimated by standard OLS).

$$
y_{t}=\lambda_{1} k_{t}+\lambda_{2} l_{t}+\lambda_{3} a_{t}+u_{t}
$$

where $y_{t}$ is log-value added in year $t=2000, \ldots, 2007, k_{t}$ is the log value of the capital stock net of amortization and depreciation, $l_{t}$ is the log value of the average number of employees per year, $a_{t}$ is the age of the firm (in years), and $u_{t}$ is the error term. The capital stock excludes all immaterial and financial assets. The average number of employees over the year is the sum of full-time regular employees, 1/2 of part-time regular employees (both items as of December 31st), and the average number of eventual workers.

Total factor productivity. $P R O D_{F E}$. Computed as the residual of sectoral estimates of equation (A1) with a fixed-effects model in order to account for unobserved time-invariant firm heterogeneity. The basic idea is as follows. If $u_{t}=\Omega+\varepsilon_{t}$, where $\varepsilon_{t}$ is an error term with usual properties and $\Omega$ is a time-invariant productivity differential that is being observed by the firm (but not the econometrician), then there may be systematic correlation between $u_{t}$ and $k_{t}$ and $l_{t}$ because the firm will incorporate this additional information in the decision of how many inputs to use (simultaneity bias). Thus, the OLS estimates are biased. With the fixed-effects specification we eliminate $\Omega$ and get consistent estimates.

Total factor productivity. $P R O D_{O P}$. Computed as the residual of estimates of equation (A1) with the Olley \& Pakes (1996) methodology. Suppose $\Omega$ changes over time such that $u_{t}=\Omega_{t}+\varepsilon_{t}$. Then, the fixed-effects model yields biased estimates. We account for this endogeneity issue by 
applying a consistent three-step estimation procedure proposed by Olley \& Pakes (1996) where capital investment $I_{t}$ is meant to proxy for the unobserved productivity shock $\Omega_{t}$. In doing so, we automatically address the selection bias problem that results from inefficient firms exiting the market and constitutes another potential source of inconsistency. For details regarding the estimation algorithm, see Olley \& Pakes (1996).

Table A1: TFP Premia (Unrestricted Sample, Mutually Exclusive Sourcing Dummies, Non-Sourcing Firms Excluded)

\begin{tabular}{|c|c|c|c|c|c|c|c|c|c|}
\hline \multirow[b]{2}{*}{ VARIABLES } & \multicolumn{3}{|c|}{ Pooled OLS } & \multicolumn{3}{|c|}{ Between Estimator } & \multicolumn{3}{|c|}{ Random Effects } \\
\hline & (1) & (2) & (3) & (4) & (5) & (6) & (7) & (8) & (9) \\
\hline$F I$ & $\begin{array}{l}0.331^{* * *} \\
(0.041)\end{array}$ & $\begin{array}{l}0.287^{* * *} \\
(0.043)\end{array}$ & $\begin{array}{l}0.142^{* * *} \\
(0.046)\end{array}$ & $\begin{array}{l}0.363^{* * *} \\
(0.045)\end{array}$ & $\begin{array}{l}0.319 * * * \\
(0.047)\end{array}$ & $\begin{array}{l}0.160^{* * *} \\
(0.050)\end{array}$ & $\begin{array}{l}0.278^{* * *} \\
(0.037)\end{array}$ & $\begin{array}{l}0.236 * * * \\
(0.039)\end{array}$ & $\begin{array}{l}0.118^{* * *} \\
(0.041)\end{array}$ \\
\hline FO & $\begin{array}{l}0.179 * * * \\
(0.025)\end{array}$ & $\begin{array}{l}0.147 * * * \\
(0.026)\end{array}$ & $\begin{array}{l}0.095^{* * *} \\
(0.026)\end{array}$ & $\begin{array}{l}0.205^{* * *} \\
(0.028)\end{array}$ & $\begin{array}{l}0.172^{* * *} \\
(0.030)\end{array}$ & $\begin{array}{l}0.115^{* * *} \\
(0.030)\end{array}$ & $\begin{array}{l}0.138^{* * *} \\
(0.023)\end{array}$ & $\begin{array}{l}0.110 * * * \\
(0.024)\end{array}$ & $\begin{array}{l}0.070 * * * \\
(0.024)\end{array}$ \\
\hline$D I$ & $\begin{array}{l}0.234^{* * *} \\
(0.045)\end{array}$ & $\begin{array}{l}0.219 * * * \\
(0.045)\end{array}$ & $\begin{array}{l}0.123 * * * \\
(0.046)\end{array}$ & $\begin{array}{l}0.253^{* * *} \\
(0.052)\end{array}$ & $\begin{array}{l}0.239 * * * \\
(0.053)\end{array}$ & $\begin{array}{l}0.133^{* *} \\
(0.053)\end{array}$ & $\begin{array}{l}0.185^{* * *} \\
(0.040)\end{array}$ & $\begin{array}{l}0.172 * * * \\
(0.040)\end{array}$ & $\begin{array}{l}0.094 * * \\
(0.040)\end{array}$ \\
\hline Age & & $\begin{array}{l}-0.000 \\
(0.001)\end{array}$ & $\begin{array}{l}-0.001 * * \\
(0.001)\end{array}$ & & $\begin{array}{l}-0.000 \\
(0.001)\end{array}$ & $\begin{array}{l}-0.001^{* *} \\
(0.001)\end{array}$ & & $\begin{array}{l}0.000 \\
(0.001)\end{array}$ & $\begin{array}{l}-0.001 * \\
(0.001)\end{array}$ \\
\hline Export & & $\begin{array}{l}0.096 * * * \\
(0.025)\end{array}$ & $\begin{array}{l}0.020 \\
(0.027)\end{array}$ & & $\begin{array}{l}0.090 * * * \\
(0.028)\end{array}$ & $\begin{array}{l}0.011 \\
(0.029)\end{array}$ & & $\begin{array}{l}0.108 * * * \\
(0.024)\end{array}$ & $\begin{array}{l}0.035 \\
(0.026)\end{array}$ \\
\hline Size & & & $\begin{array}{l}0.090 * * * \\
(0.010)\end{array}$ & & & $\begin{array}{l}0.090 * * * \\
(0.010)\end{array}$ & & & $\begin{array}{l}0.090^{* * *} \\
(0.010)\end{array}$ \\
\hline Constant & $\begin{array}{l}8.352 * * * \\
(0.065) \\
\end{array}$ & $\begin{array}{l}8.309 * * * \\
(0.067)\end{array}$ & $\begin{array}{l}8.019 * * * \\
(0.075)\end{array}$ & $\begin{array}{l}8.332 * * * \\
(0.067)\end{array}$ & $\begin{array}{l}8.293 * * * \\
(0.069) \\
\end{array}$ & $\begin{array}{l}8.005^{* * *} \\
(0.075) \\
\end{array}$ & $\begin{array}{l}8.372^{* * *} \\
(0.067)\end{array}$ & $\begin{array}{l}8.317 * * * \\
(0.069)\end{array}$ & $\begin{array}{l}8.021 * * * \\
(0.077)\end{array}$ \\
\hline Industry Fixed Effects & Yes & Yes & Yes & Yes & Yes & Yes & Yes & Yes & Yes \\
\hline Year Fixed Effects & Yes & Yes & Yes & No & No & No & Yes & Yes & Yes \\
\hline$H 0: F I=F O$ & 0.00 & 0.00 & 0.28 & 0.00 & 0.00 & 0.34 & 0.00 & 0.00 & 0.22 \\
\hline$H 0: F I=D I$ & 0.08 & 0.22 & 0.72 & 0.09 & 0.22 & 0.67 & 0.05 & 0.19 & 0.62 \\
\hline$H 0: F O=D I$ & 0.22 & 0.12 & 0.54 & 0.37 & 0.22 & 0.75 & 0.24 & 0.13 & 0.54 \\
\hline Observations & 3717 & 3717 & 3717 & 3717 & 3717 & 3717 & 3717 & 3717 & 3717 \\
\hline$R^{2}$ & 0.15 & 0.15 & 0.18 & 0.17 & 0.18 & 0.21 & 0.17 & 0.18 & 0.21 \\
\hline
\end{tabular}

The table gives estimation results obtained with the Bernard \& Jensen (1999) methodology. Each column represents a separate regression where the dependent variable $P R O D_{O P}$ is a function of dummy variables for foreign integration $(F I)$, foreign outsourcing $(F O)$, domestic integration $(D I)$, and a firm's size in terms of employees $(S I Z E)$, age $(A G E)$, and export status (EXPORT). The sourcing dummies are mutually exclusive. If a firm is active in two or more sourcing modes simultaneously, it is assigned to the category which is supposed to be associated with the highest fixed costs. The sample includes firms with domestic or foreign parent companies but excludes non-sourcing firms. The lower part of the table gives $p$-values of tests for equality of coefficients. Robust standard errors are clustered by firm (except for the between estimator) and given in parentheses. The size variable is in natural logs. ${ }^{*}, * * * *$ indicate significance at the $10 \%, 5 \%, 1 \%$ levels, respectively. 
Table A2: TFP Premia (Unrestricted Sample, Mutually Exclusive Sourcing Dummies, Non-Sourcing Firms Included)

\begin{tabular}{|c|c|c|c|c|c|c|c|c|c|}
\hline \multirow[b]{2}{*}{ VARIABLES } & \multicolumn{3}{|c|}{ Pooled OLS } & \multicolumn{3}{|c|}{ Between Estimator } & \multicolumn{3}{|c|}{ Random Effects } \\
\hline & (1) & $(2)$ & (3) & (4) & (5) & (6) & (7) & (8) & (9) \\
\hline$F I$ & $\begin{array}{l}0.292 * * * \\
(0.052)\end{array}$ & $\begin{array}{l}0.246 * * * \\
(0.052)\end{array}$ & $\begin{array}{l}0.104^{*} \\
(0.053)\end{array}$ & $\begin{array}{l}0.307^{* * *} \\
(0.069)\end{array}$ & $\begin{array}{l}0.264 * * * \\
(0.070)\end{array}$ & $\begin{array}{l}0.111 \\
(0.071)\end{array}$ & $\begin{array}{l}0.243 * * * \\
(0.045)\end{array}$ & $\begin{array}{l}0.204 * * * \\
(0.045)\end{array}$ & $\begin{array}{l}0.089^{*} \\
(0.046)\end{array}$ \\
\hline FO & $\begin{array}{l}0.140 * * * \\
(0.041)\end{array}$ & $\begin{array}{l}0.109 * * * \\
(0.040)\end{array}$ & $\begin{array}{l}0.058 \\
(0.039)\end{array}$ & $\begin{array}{l}0.149 * * \\
(0.060)\end{array}$ & $\begin{array}{l}0.119 * * \\
(0.060)\end{array}$ & $\begin{array}{l}0.067 \\
(0.059)\end{array}$ & $\begin{array}{l}0.103 * * * \\
(0.034)\end{array}$ & $\begin{array}{l}0.078^{* *} \\
(0.034)\end{array}$ & $\begin{array}{l}0.039 \\
(0.033)\end{array}$ \\
\hline$D I$ & $\begin{array}{l}0.195 * * * \\
(0.055)\end{array}$ & $\begin{array}{l}0.183 * * * \\
(0.054)\end{array}$ & $\begin{array}{l}0.088 \\
(0.054)\end{array}$ & $\begin{array}{l}0.198^{* * *} \\
(0.075)\end{array}$ & $\begin{array}{l}0.189 * * \\
(0.075)\end{array}$ & $\begin{array}{l}0.086 \\
(0.074)\end{array}$ & $\begin{array}{l}0.147 * * * \\
(0.046)\end{array}$ & $\begin{array}{l}0.138 * * * \\
(0.046)\end{array}$ & $\begin{array}{l}0.0634 \\
(0.046)\end{array}$ \\
\hline DO & $\begin{array}{l}-0.037 \\
(0.039)\end{array}$ & $\begin{array}{l}-0.032 \\
(0.038)\end{array}$ & $\begin{array}{l}-0.032 \\
(0.037)\end{array}$ & $\begin{array}{l}-0.055 \\
(0.059)\end{array}$ & $\begin{array}{l}-0.047 \\
(0.059)\end{array}$ & $\begin{array}{l}-0.042 \\
(0.058)\end{array}$ & $\begin{array}{l}-0.031 \\
(0.032)\end{array}$ & $\begin{array}{l}-0.026 \\
(0.031)\end{array}$ & $\begin{array}{l}-0.026 \\
(0.030)\end{array}$ \\
\hline Age & & $\begin{array}{l}-0.000 \\
(0.001)\end{array}$ & $\begin{array}{l}-0.001 * * \\
(0.001)\end{array}$ & & $\begin{array}{l}-0.000 \\
(0.001)\end{array}$ & $\begin{array}{l}-0.001^{* *} \\
(0.001)\end{array}$ & & $\begin{array}{l}0.000 \\
(0.001)\end{array}$ & $\begin{array}{l}-0.001 * * \\
(0.001)\end{array}$ \\
\hline Export & & $\begin{array}{l}0.110^{* * *} \\
(0.024)\end{array}$ & $\begin{array}{l}0.032 \\
(0.026)\end{array}$ & & $\begin{array}{l}0.103 * * * \\
(0.028)\end{array}$ & $\begin{array}{l}0.023 \\
(0.028)\end{array}$ & & $\begin{array}{l}0.117 * * * \\
(0.023)\end{array}$ & $\begin{array}{l}0.044^{*} \\
(0.025)\end{array}$ \\
\hline Size & & & $\begin{array}{l}0.090 * * * \\
(0.010)\end{array}$ & & & $\begin{array}{l}0.091 * * * \\
(0.010)\end{array}$ & & & $\begin{array}{l}0.090 * * * \\
(0.010)\end{array}$ \\
\hline Constant & $\begin{array}{l}8.393 * * * \\
(0.072)\end{array}$ & $\begin{array}{l}8.336 * * * \\
(0.074)\end{array}$ & $\begin{array}{l}8.047 * * * \\
(0.080)\end{array}$ & $\begin{array}{l}8.396 * * * \\
(0.085)\end{array}$ & $\begin{array}{l}8.339 * * * \\
(0.087)\end{array}$ & $\begin{array}{l}8.046 * * * \\
(0.091)\end{array}$ & $\begin{array}{l}8.411 * * * \\
(0.071)\end{array}$ & $\begin{array}{l}8.343 * * * \\
(0.073)\end{array}$ & $\begin{array}{l}8.045^{* * *} \\
(0.079)\end{array}$ \\
\hline Industry Fixed Effects & Yes & Yes & Yes & Yes & Yes & Yes & Yes & Yes & Yes \\
\hline Year Fixed Effects & Yes & Yes & Yes & No & No & No & Yes & Yes & Yes \\
\hline$H 0: F I=F O$ & 0.00 & 0.00 & 0.29 & 0.00 & 0.00 & 0.33 & 0.00 & 0.00 & 0.21 \\
\hline$H 0: F I=D I$ & 0.08 & 0.26 & 0.77 & 0.09 & 0.25 & 0.69 & 0.04 & 0.18 & 0.59 \\
\hline$H 0: F O=D I$ & 0.22 & 0.11 & 0.51 & 0.37 & 0.20 & 0.72 & 0.26 & 0.13 & 0.54 \\
\hline$H 0: F I=D O$ & 0.00 & 0.00 & 0.00 & 0.00 & 0.00 & 0.00 & 0.00 & 0.00 & 0.00 \\
\hline$H 0: F O=D O$ & 0.00 & 0.00 & 0.00 & 0.00 & 0.00 & 0.00 & 0.00 & 0.00 & 0.01 \\
\hline$H 0: D I=D O$ & 0.00 & 0.00 & 0.01 & 0.00 & 0.00 & 0.02 & 0.00 & 0.00 & 0.02 \\
\hline Observations & 3915 & 3915 & 3915 & 3915 & 3915 & 3915 & 3915 & 3915 & 3915 \\
\hline$R^{2}$ & 0.15 & 0.15 & 0.18 & 0.17 & 0.18 & 0.21 & 0.17 & 0.18 & 0.21 \\
\hline
\end{tabular}

The table gives estimation results obtained with the Bernard \& Jensen (1999) methodology. Each column represents a separate regression where the dependent variable $P R O D_{O P}$ is a function of dummy variables for foreign integration $(F I)$, foreign outsourcing $(F O)$, domestic integration $(D I)$, domestic outsourcing (DO), and a firm's size in terms of employees $(S I Z E)$, age $(A G E)$, and export status $(E X P O R T)$. The sourcing dummies are mutually exclusive. If a firm is active in two or more sourcing modes simultaneously, it is assigned to the category which is supposed to be associated with the highest fixed costs. The sample includes firms with domestic or foreign parent companies as well as non-sourcing firms. The lower part of the table gives $p$-values of tests for equality of coefficients. Robust standard errors are clustered by firm (except for the between estimator) and given in parentheses. The size variable is in natural logs. $* * *, * * *$ indicate significance at the $10 \%, 5 \%, 1 \%$ levels, respectively. 
Table A3: TFP Premia (Unrestricted Sample, Mutually Inclusive Sourcing Dummies, Non-Sourcing Firms Excluded)

\begin{tabular}{|c|c|c|c|c|c|c|c|c|c|}
\hline \multirow[b]{2}{*}{ VARIABLES } & \multicolumn{3}{|c|}{ Pooled OLS } & \multicolumn{3}{|c|}{ Between Estimator } & \multicolumn{3}{|c|}{ Random Effects } \\
\hline & $(1)$ & $(2)$ & (3) & $(4)$ & (5) & (6) & (7) & $(8)$ & (9) \\
\hline$F I$ & $\begin{array}{l}0.159 * * * \\
(0.042)\end{array}$ & $\begin{array}{l}0.139 * * * \\
(0.042)\end{array}$ & $\begin{array}{l}0.053 \\
(0.043)\end{array}$ & $\begin{array}{l}0.169 * * * \\
(0.045)\end{array}$ & $\begin{array}{l}0.149 * * * \\
(0.045)\end{array}$ & $\begin{array}{l}0.054 \\
(0.045)\end{array}$ & $\begin{array}{l}0.142 * * * \\
(0.038)\end{array}$ & $\begin{array}{l}0.123 * * * \\
(0.038)\end{array}$ & $\begin{array}{l}0.052 \\
(0.039)\end{array}$ \\
\hline FO & $\begin{array}{l}0.114 * * * \\
(0.023)\end{array}$ & $\begin{array}{l}0.083 * * * \\
(0.025)\end{array}$ & $\begin{array}{l}0.048 * * \\
(0.024)\end{array}$ & $\begin{array}{l}0.139 * * * \\
(0.027)\end{array}$ & $\begin{array}{l}0.106 * * * \\
(0.028)\end{array}$ & $\begin{array}{l}0.068 * * \\
(0.028)\end{array}$ & $\begin{array}{l}0.085 * * * \\
(0.021)\end{array}$ & $\begin{array}{l}0.058 * * * \\
(0.022)\end{array}$ & $\begin{array}{l}0.033 \\
(0.022)\end{array}$ \\
\hline$D I$ & $\begin{array}{l}0.148 * * * \\
(0.034)\end{array}$ & $\begin{array}{l}0.140 * * * \\
(0.035)\end{array}$ & $\begin{array}{l}0.058 \\
(0.036)\end{array}$ & $\begin{array}{l}0.155^{* * *} \\
(0.035)\end{array}$ & $\begin{array}{l}0.147 * * * \\
(0.035)\end{array}$ & $\begin{array}{l}0.061^{*} \\
(0.035)\end{array}$ & $\begin{array}{l}0.125 * * * \\
(0.031)\end{array}$ & $\begin{array}{l}0.117^{* * * *} \\
(0.031)\end{array}$ & $\begin{array}{l}0.048 \\
(0.033)\end{array}$ \\
\hline Age & & $\begin{array}{l}0.000 \\
(0.001)\end{array}$ & $\begin{array}{l}-0.001 * * \\
(0.001)\end{array}$ & & $\begin{array}{l}0.000 \\
(0.001)\end{array}$ & $\begin{array}{l}-0.001^{* *} \\
(0.001)\end{array}$ & & $\begin{array}{l}0.000 \\
(0.001)\end{array}$ & $\begin{array}{l}-0.001 * \\
(0.001)\end{array}$ \\
\hline Export & & $\begin{array}{l}0.108 * * * \\
(0.025)\end{array}$ & $\begin{array}{l}0.029 \\
(0.027)\end{array}$ & & $\begin{array}{l}0.102 * * * \\
(0.028)\end{array}$ & $\begin{array}{l}0.020 \\
(0.029)\end{array}$ & & $\begin{array}{l}0.117^{* * * *} \\
(0.024)\end{array}$ & $\begin{array}{l}0.042 \\
(0.026)\end{array}$ \\
\hline Size & & & $\begin{array}{l}0.092 * * * \\
(0.011)\end{array}$ & & & $\begin{array}{l}0.093 * * * \\
(0.011)\end{array}$ & & & $\begin{array}{l}0.091 * * * \\
(0.011)\end{array}$ \\
\hline Constant & $\begin{array}{l}8.362 * * * \\
(0.063) \\
\end{array}$ & $\begin{array}{l}8.310 * * * \\
(0.066) \\
\end{array}$ & $\begin{array}{l}8.019 * * * \\
(0.074) \\
\end{array}$ & $\begin{array}{l}8.343 * * * \\
(0.067) \\
\end{array}$ & $\begin{array}{l}8.294^{* * *} \\
(0.069) \\
\end{array}$ & $\begin{array}{l}8.004 * * * \\
(0.075) \\
\end{array}$ & $\begin{array}{l}8.378 * * * \\
(0.065) \\
\end{array}$ & $\begin{array}{l}8.316 * * * \\
(0.068) \\
\end{array}$ & $\begin{array}{l}8.021 * * * \\
(0.077)\end{array}$ \\
\hline Industry Fixed Effects & Yes & Yes & Yes & Yes & Yes & Yes & Yes & Yes & Yes \\
\hline Year Fixed Effects & Yes & Yes & Yes & No & No & No & Yes & Yes & Yes \\
\hline$H 0: F I=F O$ & 0.40 & 0.29 & 0.93 & 0.59 & 0.44 & 0.79 & 0.24 & 0.18 & 0.69 \\
\hline$H 0: F I=D I$ & 0.85 & 0.99 & 0.94 & 0.82 & 0.97 & 0.90 & 0.73 & 0.91 & 0.92 \\
\hline$H 0: F O=D I$ & 0.40 & 0.17 & 0.83 & 0.73 & 0.37 & 0.88 & 0.28 & 0.12 & 0.70 \\
\hline Observations & 3717 & 3717 & 3717 & 3717 & 3717 & 3717 & 3717 & 3717 & 3717 \\
\hline$R^{2}$ & 0.14 & 0.15 & 0.17 & 0.17 & 0.17 & 0.20 & 0.17 & 0.17 & 0.21 \\
\hline
\end{tabular}

The table gives estimation results obtained with the Bernard \& Jensen (1999) methodology. Each column represents a separate regression where the dependent variable $P R O D_{O P}$ is a function of dummy variables for foreign integration $(F I)$, foreign outsourcing $(F O)$, domestic integration $(D I)$, and a firm's size in terms of employees ( $S I Z E)$, age $(A G E)$, and export status (EXPORT). The sourcing dummies are mutually inclusive. The sample includes firms with domestic or foreign parent companies but excludes non-sourcing firms. The lower part of the table gives p-values of tests for equality of coefficients. Robust standard errors are clustered by firm (except for the between estimator) and given in parentheses. The size variable is in natural logs. $*, * *, * * *$ indicate significance at the $10 \%, 5 \%, 1 \%$ levels, respectively. 
Table A4: TFP Premia (Unrestricted Sample, Mutually Inclusive Sourcing Dummies, Non-Sourcing Firms Included)

\begin{tabular}{|c|c|c|c|c|c|c|c|c|c|}
\hline \multirow[b]{2}{*}{ VARIABLES } & \multicolumn{3}{|c|}{ Pooled OLS } & \multicolumn{2}{|c|}{ Between Estimator } & \multirow[b]{2}{*}{ (6) } & \multicolumn{2}{|c|}{ Random Effects } & \multirow[b]{2}{*}{ (9) } \\
\hline & (1) & (2) & (3) & (4) & (5) & & (7) & (8) & \\
\hline$F I$ & $\begin{array}{l}0.158 * * * \\
(0.042)\end{array}$ & $\begin{array}{l}0.136 * * * \\
(0.042)\end{array}$ & $\begin{array}{l}0.052 \\
(0.043)\end{array}$ & $\begin{array}{l}0.167 * * * \\
(0.044)\end{array}$ & $\begin{array}{l}0.145 * * * \\
(0.045)\end{array}$ & $\begin{array}{l}0.053 \\
(0.045)\end{array}$ & $\begin{array}{l}0.143^{* * *} \\
(0.038)\end{array}$ & $\begin{array}{l}0.123 * * * \\
(0.038)\end{array}$ & $\begin{array}{l}0.054 \\
(0.038)\end{array}$ \\
\hline$F O$ & $\begin{array}{l}0.111 * * * \\
(0.023)\end{array}$ & $\begin{array}{l}0.077 * * * \\
(0.024)\end{array}$ & $\begin{array}{l}0.042 * \\
(0.024)\end{array}$ & $\begin{array}{l}0.135 * * * \\
(0.026)\end{array}$ & $\begin{array}{l}0.098 * * * \\
(0.028)\end{array}$ & $\begin{array}{l}0.060 * * \\
(0.028)\end{array}$ & $\begin{array}{l}0.081 * * * \\
(0.021)\end{array}$ & $\begin{array}{l}0.054 * * \\
(0.022)\end{array}$ & $\begin{array}{l}0.028 \\
(0.021)\end{array}$ \\
\hline$D I$ & $\begin{array}{l}0.146 * * * \\
(0.034)\end{array}$ & $\begin{array}{l}0.137 * * * \\
(0.034)\end{array}$ & $\begin{array}{l}0.056 \\
(0.036)\end{array}$ & $\begin{array}{l}0.152 * * * \\
(0.034)\end{array}$ & $\begin{array}{l}0.143 * * * \\
(0.034)\end{array}$ & $\begin{array}{l}0.058 \\
(0.035)\end{array}$ & $\begin{array}{l}0.121 * * * \\
(0.031)\end{array}$ & $\begin{array}{l}0.113 * * * \\
(0.031)\end{array}$ & $\begin{array}{l}0.045 \\
(0.032)\end{array}$ \\
\hline$D O$ & $\begin{array}{l}-0.002 \\
(0.032)\end{array}$ & $\begin{array}{l}0.002 \\
(0.032)\end{array}$ & $\begin{array}{l}0.012 \\
(0.031)\end{array}$ & $\begin{array}{l}-0.019 \\
(0.044)\end{array}$ & $\begin{array}{l}-0.013 \\
(0.044)\end{array}$ & $\begin{array}{l}0.003 \\
(0.044)\end{array}$ & $\begin{array}{l}-0.004 \\
(0.028)\end{array}$ & $\begin{array}{l}-0.001 \\
(0.027)\end{array}$ & $\begin{array}{l}0.005 \\
(0.027)\end{array}$ \\
\hline Age & & $\begin{array}{l}0.000 \\
(0.001)\end{array}$ & $\begin{array}{l}-0.001 * * \\
(0.001)\end{array}$ & & $\begin{array}{l}0.000 \\
(0.001)\end{array}$ & $\begin{array}{l}-0.001 * * \\
(0.001)\end{array}$ & & $\begin{array}{l}0.000 \\
(0.001)\end{array}$ & $\begin{array}{l}-0.001 * \\
(0.001)\end{array}$ \\
\hline Export & & $\begin{array}{l}0.121 * * * \\
(0.024)\end{array}$ & $\begin{array}{l}0.041 \\
(0.026)\end{array}$ & & $\begin{array}{l}0.115 * * * \\
(0.027)\end{array}$ & $\begin{array}{l}0.032 \\
(0.028)\end{array}$ & & $\begin{array}{l}0.124^{* * *} \\
(0.023)\end{array}$ & $\begin{array}{l}0.050 * * \\
(0.025)\end{array}$ \\
\hline Size & & & $\begin{array}{l}0.092 * * * \\
(0.010)\end{array}$ & & & $\begin{array}{l}0.093^{* * *} \\
(0.010)\end{array}$ & & & $\begin{array}{l}0.092 * * * \\
(0.010)\end{array}$ \\
\hline Constant & $\begin{array}{l}8.370 * * * \\
(0.068)\end{array}$ & $\begin{array}{l}8.305^{* * *} \\
(0.070)\end{array}$ & $\begin{array}{l}8.006 * * * \\
(0.077) \\
\end{array}$ & $\begin{array}{l}8.372 * * * \\
(0.076) \\
\end{array}$ & $\begin{array}{l}8.308 * * * \\
(0.078) \\
\end{array}$ & $\begin{array}{l}8.003^{* * *} \\
(0.084)\end{array}$ & $\begin{array}{l}8.391^{* * *} \\
(0.068) \\
\end{array}$ & $\begin{array}{l}8.318^{* * *} \\
(0.070)\end{array}$ & $\begin{array}{l}8.016 * * * \\
(0.079)\end{array}$ \\
\hline Industry Fixed Effects & Yes & Yes & Yes & Yes & Yes & Yes & Yes & Yes & Yes \\
\hline Year Fixed Effects & Yes & Yes & Yes & No & No & No & Yes & Yes & Yes \\
\hline$H 0: F I=F O$ & 0.38 & 0.27 & 0.86 & 0.57 & 0.40 & 0.90 & 0.20 & 0.16 & 0.60 \\
\hline$H 0: F I=D I$ & 0.83 & 0.99 & 0.94 & 0.79 & 0.97 & 0.93 & 0.67 & 0.86 & 0.86 \\
\hline$H 0: F O=D I$ & 0.40 & 0.15 & 0.75 & 0.72 & 0.32 & 0.96 & 0.28 & 0.12 & 0.66 \\
\hline$H 0: F I=D O$ & 0.00 & 0.01 & 0.46 & 0.00 & 0.01 & 0.43 & 0.00 & 0.01 & 0.31 \\
\hline$H 0: F O=D O$ & 0.01 & 0.08 & 0.47 & 0.00 & 0.04 & 0.30 & 0.02 & 0.13 & 0.52 \\
\hline$H 0: D I=D O$ & 0.00 & 0.00 & 0.35 & 0.00 & 0.01 & 0.33 & 0.00 & 0.00 & 0.33 \\
\hline Observations & 3915 & 3915 & 3915 & 3915 & 3915 & 3915 & 3915 & 3915 & 3915 \\
\hline$R^{2}$ & 0.14 & 0.15 & 0.18 & 0.17 & 0.17 & 0.21 & 0.17 & 0.17 & 0.21 \\
\hline
\end{tabular}

The table gives estimation results obtained with the Bernard \& Jensen (1999) methodology. Each column represents a separate regression where the dependent variable $P R O D_{O P}$ is a function of dummy variables for foreign integration $(F I)$, foreign outsourcing $(F O)$, domestic integration $(D I)$, domestic outsourcing (DO), and a firm's size in terms of employees (SIZE), age $(A G E)$, and export status $(E X P O R T)$. The sourcing dummies are mutually inclusive. The sample includes firms with domestic or foreign parent companies as well as non-sourcing firms. The lower part of the table gives $p$-values of tests for equality of coefficients. Robust standard errors are clustered by firm (except for the between estimator) and given in parentheses. The size variable is in natural logs. $* * *, * * *$ indicate significance at the $10 \%, 5 \%, 1 \%$ levels, respectively. 


\section{CESifo Working Paper Series}

for full list see www.cesifo-group.org/wp

(address: Poschingerstr. 5, 81679 Munich, Germany, office@cesifo.de)

2841 Andreas Knabe, Steffen Rätzel and Stephan L. Thomsen, Right-Wing Extremism and the Well-Being of Immigrants, October 2009

2842 Andrea Weber and Christine Zulehner, Competition and Gender Prejudice: Are Discriminatory Employers Doomed to Fail?, November 2009

2843 Hadi Salehi Esfahani, Kamiar Mohaddes and M. Hashem Pesaran, Oil Exports and the Iranian Economy, November 2009

2844 Ruediger Bachmann and Christian Bayer, Firm-Specific Productivity Risk over the Business Cycle: Facts and Aggregate Implications, November 2009

2845 Guglielmo Maria Caporale, Burcu Erdogan and Vladimir Kuzin, Testing for Convergence in Stock Markets: A Non-Linear Factor Approach, November 2009

2846 Michèle Belot and Jan Fidrmuc, Anthropometry of Love - Height and Gender Asymmetries in Interethnic Marriages, November 2009

2847 Volker Nitsch and Nikolaus Wolf, Tear Down this Wall: On the Persistence of Borders in Trade, November 2009

2848 Jan K. Brueckner and Stef Proost, Carve-Outs Under Airline Antitrust Immunity, November 2009

2849 Margarita Katsimi and Vassilis Sarantides, The Impact of Fiscal Policy on Profits, November 2009

2850 Scott Alan Carson, The Relationship between Stature and Insolation: Evidence from Soldiers and Prisoners, November 2009

2851 Horst Raff and Joachim Wagner, Intra-Industry Adjustment to Import Competition: Theory and Application to the German Clothing Industry, November 2009

2852 Erkki Koskela, Impacts of Labor Taxation with Perfectly and Imperfectly Competitive Labor Markets under Flexible Outsourcing, November 2009

2853 Cletus C. Coughlin and Dennis Novy, Is the International Border Effect Larger than the Domestic Border Effect? Evidence from U.S. Trade, November 2009

2854 Johannes Becker and Clemens Fuest, Source versus Residence Based Taxation with International Mergers and Acquisitions, November 2009

2855 Andreas Hoffmann and Gunther Schnabl, A Vicious Cycle of Manias, Crashes and Asymmetric Policy Responses - An Overinvestment View, November 2009 
2856 Xavier Vives, Strategic Supply Function Competition with Private Information, November 2009

2857 M. Hashem Pesaran and Paolo Zaffaroni, Optimality and Diversifiability of Mean Variance and Arbitrage Pricing Portfolios, November 2009

2858 Davide Sala, Philipp J.H. Schröder and Erdal Yalcin, Market Access through Bound Tariffs, November 2009

2859 Ben J. Heijdra and Pim Heijnen, Environmental Policy and the Macroeconomy under Shallow-Lake Dynamics, November 2009

2860 Enrico Spolaore, National Borders, Conflict and Peace, November 2009

2861 Nina Czernich, Oliver Falck, Tobias Kretschmer and Ludger Woessmann, Broadband Infrastructure and Economic Growth, December 2009

2862 Evžen Kočenda and Martin Vojtek, Default Predictors and Credit Scoring Models for Retail Banking, December 2009

2863 Christian Gollier and Martin L. Weitzman, How Should the Distant Future be Discounted when Discount Rates are Uncertain?, December 2009

2864 Tiberiu Dragu and Mattias Polborn, Terrorism Prevention and Electoral Accountability, December 2009

2865 Torfinn Harding and Beata Smarzynska Javorcik, A Touch of Sophistication: FDI and Unit Values of Exports, December 2009

2866 Matthias Dischinger and Nadine Riedel, There's no Place like Home: The Profitability Gap between Headquarters and their Foreign Subsidiaries, December 2009

2867 Andreas Haufler and Frank Stähler, Tax Competition in a Simple Model with Heterogeneous Firms: How Larger Markets Reduce Profit Taxes, December 2009

2868 Steinar Holden, Do Choices Affect Preferences? Some Doubts and New Evidence, December 2009

2869 Alberto Asquer, On the many Ways Europeanization Matters: The Implementation of the Water Reform in Italy (1994-2006), December 2009

2870 Choudhry Tanveer Shehzad and Jakob De Haan, Financial Reform and Banking Crises, December 2009

2871 Annette Alstadsæter and Hans Henrik Sievertsen, The Consumption Value of Higher Education, December 2009

2872 Chris van Klaveren, Bernard van Praag and Henriette Maassen van den Brink, Collective Labor Supply of Native Dutch and Immigrant Households in the Netherlands, December 2009 
2873 Burkhard Heer and Alfred Maußner, Computation of Business-Cycle Models with the Generalized Schur Method, December 2009

2874 Carlo Carraro, Enrica De Cian and Massimo Tavoni, Human Capital Formation and Global Warming Mitigation: Evidence from an Integrated Assessment Model, December 2009

2875 André Grimaud, Gilles Lafforgue and Bertrand Magné, Climate Change Mitigation Options and Directed Technical Change: A Decentralized Equilibrium Analysis, December 2009

2876 Angel de la Fuente, A Mixed Splicing Procedure for Economic Time Series, December 2009

2877 Martin Schlotter, Guido Schwerdt and Ludger Woessmann, Econometric Methods for Causal Evaluation of Education Policies and Practices: A Non-Technical Guide, December 2009

2878 Mathias Dolls, Clemens Fuest and Andreas Peichl, Automatic Stabilizers and Economic Crisis: US vs. Europe, December 2009

2879 Tom Karkinsky and Nadine Riedel, Corporate Taxation and the Choice of Patent Location within Multinational Firms, December 2009

2880 Kai A. Konrad, Florian Morath and Wieland Müller, Taxation and Market Power, December 2009

2881 Marko Koethenbuerger and Michael Stimmelmayr, Corporate Taxation and Corporate Governance, December 2009

2882 Gebhard Kirchgässner, The Lost Popularity Function: Are Unemployment and Inflation no longer Relevant for the Behaviour of Germany Voters?, December 2009

2883 Marianna Belloc and Ugo Pagano, Politics-Business Interaction Paths, December 2009

2884 Wolfgang Buchholz, Richard Cornes and Dirk Rübbelke, Existence and Warr Neutrality for Matching Equilibria in a Public Good Economy: An Aggregative Game Approach, December 2009

2885 Charles A.E. Goodhart, Carolina Osorio and Dimitrios P. Tsomocos, Analysis of Monetary Policy and Financial Stability: A New Paradigm, December 2009

2886 Thomas Aronsson and Erkki Koskela, Outsourcing, Public Input Provision and Policy Cooperation, December 2009

2887 Andreas Ortmann, "The Way in which an Experiment is Conducted is Unbelievably Important": On the Experimentation Practices of Economists and Psychologists, December 2009 
2888 Andreas Irmen, Population Aging and the Direction of Technical Change, December 2009

2889 Wolf-Heimo Grieben and Fuat Şener, Labor Unions, Globalization, and Mercantilism, December 2009

2890 Conny Wunsch, Optimal Use of Labor Market Policies: The Role of Job Search Assistance, December 2009

2891 Claudia Buch, Cathérine Tahmee Koch and Michael Kötter, Margins of International Banking: Is there a Productivity Pecking Order in Banking, too?, December 2009

2892 Shafik Hebous and Alfons J. Weichenrieder, Debt Financing and Sharp Currency Depreciations: Wholly vs. Partially Owned Multinational Affiliates, December 2009

2893 Johannes Binswanger and Daniel Schunk, What is an Adequate Standard of Living during Retirement?, December 2009

2894 Armin Falk and James J. Heckman, Lab Experiments are a Major Source of Knowledge in the Social Sciences, December 2009

2895 Hartmut Egger and Daniel Etzel, The Impact of Trade on Employment, Welfare, and Income Distribution in Unionized General Oligopolistic Equilibrium, December 2009

2896 Julian Rauchdobler, Rupert Sausgruber and Jean-Robert Tyran, Voting on Thresholds for Public Goods: Experimental Evidence, December 2009

2897 Michael McBride and Stergios Skaperdas, Conflict, Settlement, and the Shadow of the Future, December 2009

2898 Ben J. Heijdra and Laurie S. M. Reijnders, Economic Growth and Longevity Risk with Adverse Selection, December 2009

2899 Johannes Becker, Taxation of Foreign Profits with Heterogeneous Multinational Firms, December 2009

2900 Douglas Gale and Piero Gottardi, Illiquidity and Under-Valuation of Firms, December 2009

2901 Donatella Gatti, Christophe Rault and Anne-Gaël Vaubourg, Unemployment and Finance: How do Financial and Labour Market Factors Interact?, December 2009

2902 Arno Riedl, Behavioral and Experimental Economics Can Inform Public Policy: Some Thoughts, December 2009

2903 Wilhelm K. Kohler and Marcel Smolka, Global Sourcing Decisions and Firm Productivity: Evidence from Spain, December 2009 